Tasmanian School of Business and Economics University of Tasmania

Understanding the Deviations of the Taylor Rule: A New Methodology with an Application to Australia

Kerry Hudson

University of Tasmania

Joaquin VESPIGNANI

University of Tasmania

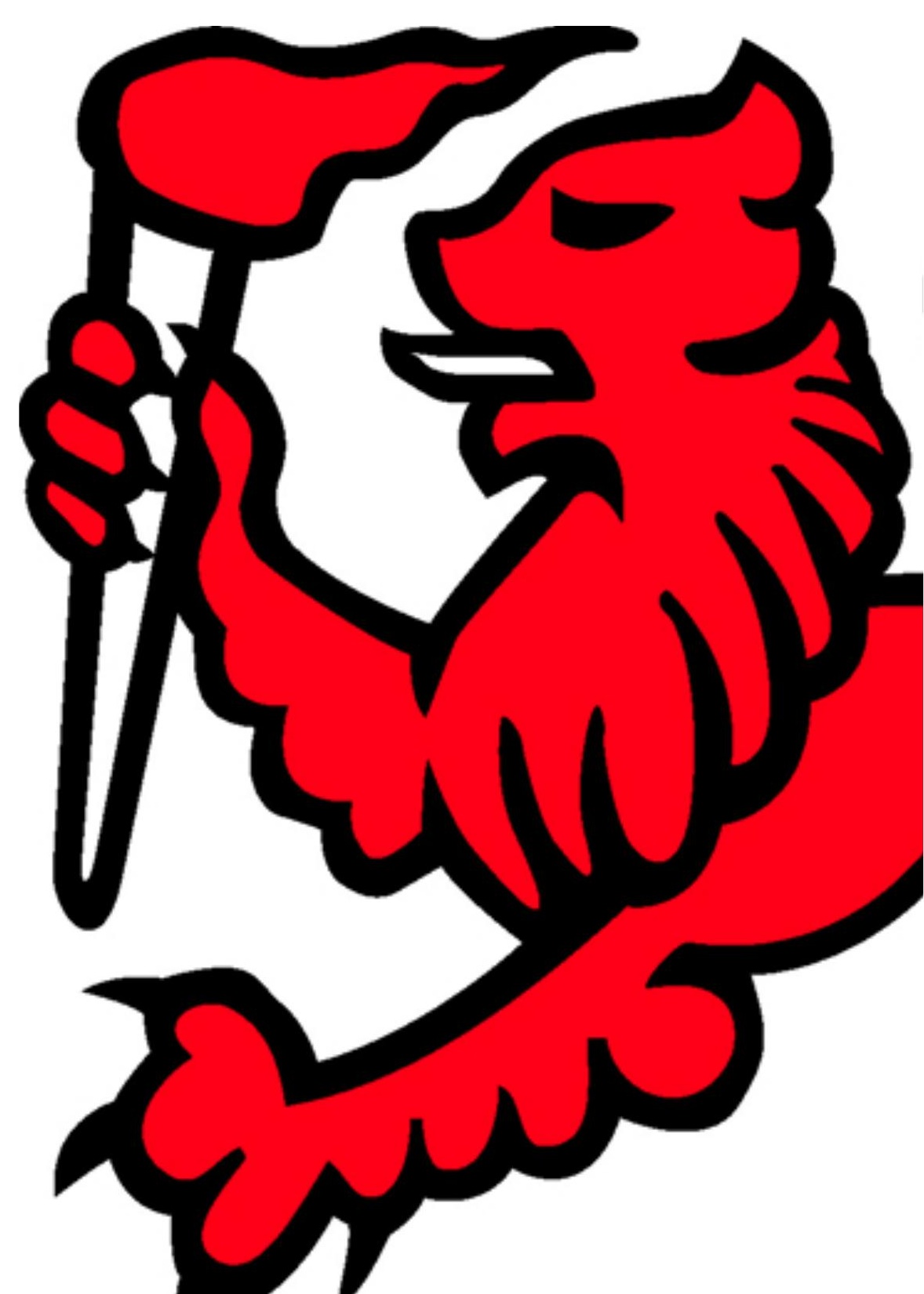




\title{
Understanding the Deviations of the Taylor Rule: A New Methodology with an Application to Australia
}

\author{
Kerry B. Hudson ${ }^{\mathrm{a}}$ and Joaquin L. Vespignani ${ }^{\mathrm{ab} \dagger}$ \\ ${ }^{a}$ University of Tasmania, Tasmanian School of Business and Economics, \\ ${ }^{\mathrm{b}}$ Centre for Applied Macroeconomic Analysis. Australia
}

\begin{abstract}
This investigation aims to explain and quantify the deviations of the Taylor Rule. A novel three-step econometric procedure designed to reflect the data-rich environment in which central banks operate is proposed using information for 229 macroeconomic series. This procedure can be applied to data for any economy with inflation targeting monetary rule. Our application with Australian data shows that approximately $65 \%$ of Australia's deviation from the Taylor Rule can be explained systematically, with international factors and a domestic factor accounting for $41.9 \%$ and $22.5 \%$ respectively of the total variation in deviation from the rule. Australian deviation from the Taylor Rule is also associated with the deviation of the US's Taylor Rule, indicating that the Reserve Bank of Australia appears to be following an international monetary policy trend set forth by the world's largest economy.
\end{abstract}

Keywords: Taylor Rule, Monetary Policy, Small Open Economy

JEL Codes: E40, E52,E50

${ }^{\dagger}$ Corresponding author: Joaquin L. Vespignani; University of Tasmania, Tasmanian School of Business and Economic, Australia; Tel. No: +61 3 62262825; E-mail address: Joaquin.Vespignani@utas.edu.au 


\section{Introduction}

Taylor (1993) proposes a simple monetary policy rule for the United States (US) in which the monetary policy instrument is a function of output gap and inflation. Asso et al. (2007) notes, since 1993, the Taylor Rule and its various augmentations have become the main method with which to analyse a central bank's reaction function and introduce monetary policy to macroeconomic models. Understanding central banks' reaction functions is critical for market operators and macroeconomics forecasters.

Bernanke et al. (2005) suggests that central banks operate in a data-rich environment in which many other variables are taken into consideration in the conduct of monetary policy. Given that central banks of small open economies (SOE) such as Australia are in general more dependent on international economies, it is expected that the monetary authorities of such economies also consider many international factors when setting the monetary policy instrument. ${ }^{1}$ In line with this rationale: are the deviations of the Taylor Rule systematic? If so, what factors explain this deviation? Can those factors be identified as domestic or international factors? Lastly, can the contribution of each factor be quantified?

In order to address these questions, an innovative three-step econometric procedure is proposed. In the first step, using real-time data, the Taylor Rule is estimated using ordinary least squares (OLS) regression and its residual is defined as the deviation from the Taylor Rule. In the second step, this residual is used as dependant variables and a set of independent variables or factors are created. Specially, 229 macroeconomic series are compressed into a small number of factors. Domestic series were chosen in line with those used by Stock and Watson (2002) and Bernanke et al. (2005). To account for Australia's status as a SOE, international factors were also chosen. This accords with the international mind-set adopted

\footnotetext{
${ }^{1}$ Note that this is evidence in the RBA's Statement of Monetary Policy and monetary Policy Decision where international economic conditions are explicitly addressed.
} 
by the Reserve Bank of Australia (RBA), reflected through its quarterly Statement on Monetary Policy. Importantly, the use of a large data set reflects Bernanke's et al. (2005) view that central banks operate in a data-rich environment in which monetary policy decisions are influenced by many factors. The final step in the methodology involved applying the Lindeman, Merenda and Gold (LMG) - Shapley decomposition methodology to decompose the explanatory power of the estimated factors. This three-step method can be applied to other economies with an inflation targeting monetary rule to uncover any systematic deviation of the Taylor Rule of a given country.

The principal finding of this investigation is that almost $65 \%$ of Australia's deviation in the Taylor Rule can be explained systematically, with international factors and a domestic factor accounting for $41.9 \%$ and $22.5 \%$ of the total variation in deviation from the rule, respectively. The lone domestic factor, domestic interest rates other than the cash rate target, accounts for the most variation of all individual factors, explaining $22.5 \%$ of the total variation in deviation from the Taylor Rule. Other domestic factors that potentially explain deviation from the rule, such as employment and other prices, are found to be statistically insignificant. Furthermore, the international factor that accounts for the largest proportion of this explained variation is exchange rates, explaining $16 \%$ of Australia's deviation from the Taylor Rule. Other international factors that account for a significant albeit smaller proportion of Australia's deviation from the rule are commodity prices, the US' deviation from its estimated Taylor Rule and international interest rates, explaining 12.5, 8.6 and 4.8\%, respectively. Importantly, the conclusion that can be drawn from the significance of the US' deviation is that Australia appears to be following international monetary policy trend set forth by the world's largest economy. 
This paper proceeds as follows: Section 2 reviews the literature. Section 3 explores different measures of output gap and inflation. In section 4, the data used is described. Section 5 proposes a three-step methodology to analyse deviation of the Taylor Rule. In section 6, results of the new methodology are reported for Australia. Section 7 concludes.

\section{Literature review}

Taylor (1993) proposes the following monetary policy rule:

$$
i_{t}=r+\bar{\pi}_{t}+0.5\left(\bar{\pi}_{t}-\pi^{*}\right)+0.5 y_{t}^{g a p}, t=1,2, \ldots, T .
$$

where $i_{t}$ is the quarterly average of the short-term interest rate, $r$ is the equilibrium real interest rate, $\bar{\pi}_{t}$ is the rate of inflation that has prevailed over the previous four quarters, $\pi^{*}$ is the central bank's inflation target and $y_{t}^{g a p}$ is the output gap, defined as the percentage deviation of real gross domestic product (GDP) from trend real GDP. The difference between $\bar{\pi}_{\mathrm{t}}$ and $\pi^{*}$ can be termed the inflation gap. Taylor (1993) estimates inflation using the GDP price deflator and trend real GDP by applying log-linear de-trending to the real GDP series. To investigate the performance of the rule relative to the actual federal funds rate, Taylor (1993) assumes the Federal Reserve targeted an annual inflation rate of two percent.

Furthermore, the equilibrium real interest rate is set equal to two percent, which is the trend growth rate of real GDP between 1984Q1 and 1992Q3 calculated by Taylor (1993). Adapting Equation 1 to these assumptions, Taylor's (1993) original rule took the following form:

$$
i_{t}=2+\bar{\pi}_{t}+0.5\left(\bar{\pi}_{t}-2\right)+0.5 y_{t}^{g a p}
$$

By inspection, it is apparent that Equation 2 is a monetary policy reaction function 
that implies that the central bank (in this case the Federal Reserve) only considers the inflation gap and the stability of real output when implementing the monetary policy instrument. Although some are critical of Taylor's parsimonious approach, including Svensson (2003), there are many proponents of simple monetary policy rules. ${ }^{2}$

Within the US, Clarida et al. (2000) estimate both backward and forward-looking Taylor Rules, the latter of which involves using forecasts of the inflation and output gaps, and conclude that the monetary policy reaction function varies over time. Orphanides (2001) highlights the importance of the choice between real-time data and current data when considering both calibrated and estimated US Taylor Rules. Specifically, Orphanides (2001) demonstrates that implied Taylor Rule interest rates calculated using real-time data can be significantly different from those utilising current data. ${ }^{3}$

The Taylor Rule has also been applied to SOE, including, but not limited to, Australia, New Zealand (NZ), Canada and Sweden. de Brouwer and O'Regan (1997) consider alternative-weight Taylor Rules among a number of simple interest rate rules and find that the Taylor Rule compares favorably to these alternative rules. Laxton and Pesenti (2003), utilising a dynamic stochastic general equilibrium (DSGE) model for a SOE, compare the effectiveness of calibrated Taylor Rules with other monetary rules. In the context of investigating the feasibility of an Australia-NZ currency union, Björksten et al. (2004) estimate Taylor Rules for both countries using a sample period of 1992 to 2002 . de Brouwer and Gilbert (2005) assess both calibrated and estimated backward and forward-

\footnotetext{
${ }^{2}$ For example: Kam (2007) argues that simple rules are credible, transparent, fathomable and robust to model uncertainty. Williams (2003) states that simple monetary policy rules are able to effectively reduce the variability of output, inflation and interest rates.

${ }^{3}$ Furthermore, Orphanides (2001) finds meaningfully different output gap and inflation gap coefficient estimates between real-time and current data. In the context of presenting an expansive overview of historical monetary policy conduct in the US, Orphanides (2003) analyses calibrated and estimated Taylor Rules for the US from 1969 to 2002 using several different data vintages. Mehra and Minton (2007) and Kahn (2012) also compare Taylor Rules estimated using different data vintages.
} 
looking Taylor Rules in Australia following the floating of the Australian dollar in December 1983. de Brouwer and Gilbert (2005) conclude that over time, the RBA's response to inflation has increased while the output gap response has decreased.

Kendall and Ng (2013) estimate backward-looking Taylor Rules for Australia and NZ from 1992 to 2012. They consider both pre-global financial crisis (GFC) and post-GFC samples in comparing the monetary policy regimes of the two countries to the US. Kendall and $\mathrm{Ng}$ (2013) conclude that the monetary policy conduct of Australia, NZ and the US are not significantly different from one another. Lee et al. (2013) consider 'meta' estimated Taylor Rules for Australia and the UK, which are constructed by applying averaging techniques to a series of estimated Taylor Rules for each country.

Arguably, the most significant alteration that has been made to Taylor Rule is the inclusion of parameters that reflect the interest rate smoothing, or partial adjustment, behaviour undertaken by central banks. Kam (2007) defines interest rate smoothing or monetary policy inertia as the propensity of central banks to change the policy instrument gradually and to be reluctant to reverse policy instrument change direction. The theoretical basis of interest rate smoothing is well documented, particularly by Goodfriend (1987), Lowe and Ellis (1997), English et al. (2003) and Woodford (2003). The main reasons for interest rate smoothing include maintaining the credibility of the central bank and stability in financial markets. English et al. (2003), Castelnuovo (2003) and Castelnuovo (2007), using US and Euro area data respectively, presents direct evidence supporting the prevalence of interest rate smoothing.

\section{Measures of output gap and inflation}

\subsection{Inflation measures}


The original Taylor Rule used the percentage change in the GDP price deflator over the previous four quarters as its measure of inflation. However, numerous other measures have been used in ensuing analysis of the Taylor Rule. Clarida et al. (1998), Gerlach and Schnabel (2000), Taylor (1999), and Mehra and Minton (2007) are among those who use the headline Consumer Price Index (CPI) and the underlying CPI respectively. ${ }^{4}$

In an Australian context, de Brouwer and Ellis (1998) note that although the RBA uses underlying CPI inflation when considering the cash rate target, headline inflation is also widely reported by mainstream media and thus is influential in forming the inflationary expectations of the public. Accordingly, this study considers three backward-looking alternative inflation measures: headline CPI inflation, trimmed mean CPI inflation and weighted median CPI inflation, the latter two of which can be categorised as measures of underlying inflation. Headline CPI inflation is measured using all groups of the CPI. The trimmed mean CPI series is the expenditure-weighted mean of the middle $70 \%$ of ordered price changes in all CPI components, while the weighted median CPI series is the expenditure-weighted median of these ordered price changes in all CPI components. All three series are seasonally adjusted. Following de Brouwer and Gilbert (2005), Leu and Sheen (2006), and Lee et al. (2013), the transitory effect of the introduction of the Goods and Services Tax (GST) is removed from the headline inflation series by subtracting three percent from the four affected quarters (2000Q3 - 2001Q2).

Figure 1 illustrates these three measures of inflation from 1994Q1 to 2013Q1. ${ }^{5}$ As expected, headline CPI inflation is clearly the most volatile measure within this period, while generally; trimmed mean CPI inflation and weighted median CPI inflation exhibited a high

\footnotetext{
${ }^{4}$ Note that Mehra and Sawhney (2010) conclude that the use of alternative inflation measures can affect the short-term interest rate implied by the Taylor Rule. Kozicki (1999) finds empirical evidence supporting this conclusion, but it is also refuted by Clarida et al. (2000).

${ }^{5}$ Note that barring exceptional circumstances, the Australian Bureau of Statistics (ABS) does not revise CPI data, meaning that the three inflation series are both real-time and current data.
} 
degree of correlation. In this figure various points of interest can be identified and are at least partially attributable to the following factors. In 1995Q3, headline inflation reached a local maximum of $5.1 \%$ due to a number of factors. Firstly, increased economic activity in 1994, which led to demand-pull inflation, particularly affecting the labour market (Reserve Bank of Australia 1995). Other factors include the depreciation of the Australian dollar, higher mortgage interest costs and increases in both the input and output costs of the manufacturing industry market (Reserve Bank of Australia 1995). In 1997Q3-Q4, headline inflation reached a local minimum of $-0.3 \%$, attributable to a reduction in mortgage interest costs and import prices, owing to an appreciated Australian dollar (Reserve Bank of Australia 1997).

Between 1998Q1 and 2000Q2, there was a generally sustained period of rising inflation, which initially was due to a depreciation of the Australian dollar (Reserve Bank of Australia 1998). This depreciation was the result of a number of international events, including the Asian crisis and subsequent events in Russia and Japan (Reserve Bank of Australia 1998). From 1999 onwards, rising oil prices and tobacco excise increases also placed upward pressure on prices (Reserve Bank of Australia 2000a). The third quarter of 1998 also coincided with a change in the methodology of the CPI formulation, in which interest and consumer credit charges were removed from the index, while new house purchase prices were added (Reserve Bank of Australia 1998). 2000Q3 coincided with the introduction of the GST, which significantly inflated the headline inflation measure for that quarter and the three subsequent quarters (Reserve Bank of Australia 2000b). ${ }^{6}$

In 2006Q3, owing to transient food price increases due to Cyclone Larry, headline inflation reached $3.8 \%$ (Reserve Bank of Australia 2011a). ${ }^{7}$ A rise in oil prices also

\footnotetext{
${ }^{6}$ The GST is a broad-based value-added tax borne entirely by the final consumer, applied to most goods and services that are sold or consumed in Australia equal, to $10 \%$ of the value of said good or service (Australian Taxation Office 2014).

${ }^{7}$ Cyclone Larry, a tropical cyclone predominantly affecting the state of Queensland, led to substantial loss of
} 
contributed to inflation growth in early 2006 (Reserve Bank of Australia 2006). In 2008Q3, headline inflation reached a local maximum of $4.8 \%$, attributable to a broad base of factors, including increases in commodity prices, a mining industry boom in certain regions of Australia, and rises in housing costs and financial and insurance services costs (Reserve Bank of Australia 2008). In 2009Q3, headline inflation reached a local minimum of $1.2 \%$, attributable to a number of factors, including declines in oil prices and deposit and loan costs, appreciation of the Australian dollar and low wage growth (Reserve Bank of Australia 2009). Cyclone Yasi, which resulted in transient food price increases contributed to a rise of inflation in 2011Q2, with inflation growing to $3.5 \%$ (Reserve Bank of Australia 2011b). ${ }^{8}$

\subsection{Output gap measures}

Orphanides (2001) establishes that real-time data output gap estimates are significantly different from those estimated using current data; he concludes that monetary policy decisions can only be accurately analysed using real-time data, as this is the real-time data that policy makers have at their disposal. In line with this reasoning and for robustness analysis, we use three measures of output gap using real-time data for the estimation of the Taylor Rule. These measures are: Linear de-trended GDP, Hodrick and Prescott (1997) (HP) filter GDP and unemployment gap.

de Brouwer (1998) asserts that the assumption of constant potential output growth is erroneous and recommends the use of time-varying methods that are able to capture the structural reforms of the economy. Consequently, we follow Nikolsko-Rzhevskyy (2011), in using a rolling sample with width $n=40$, which is 10 years in the estimation of linear output

banana crop (Reserve Bank of Australia 2011a). Richards and Rosewall (2010) note that the RBA estimates that banana price increased by approximately $400 \%$ immediately following the cyclone and that the resulting affect on inflation was around $0.75 \%$, which was subsequently further compounded by quarantine restrictions that prevented bananas being imported (Reserve Bank of Australia 2011a).

${ }^{8}$ Cyclone Yasi was also a tropical cyclone primarily affecting Queensland that damaged the banana crop in that area and similarly increased banana prices, food prices and thus headline inflation (Reserve Bank of Australia 2011b). 
gap. Specifically, for each sample, the output gap estimated for the final observation of that sample was recorded as the output gap for that particular observation date. Alternatively, the output gap is estimated using a HP filter, applying the commonly employed smoothing parameter $\lambda$ equal to $1600 .{ }^{9}$ We follow Stock and Watson (2003) in the use of a one-sided HP filter that uses only the data that would have been available at the time to estimate each potential output value. ${ }^{10}$ Following Pinkwart (2013), an extended sample is used to ensure the soundness of potential output estimates early in the sample.

A third alternative measure of the output gap was also considered by implementing a common modification of the Taylor Rule. This modification, relying upon the relationship between unemployment and output specified by Okun's law (1962), involves substituting the output gap with the unemployment gap. Taylor (1999), Orphanides and Williams (2002), and Orphanides and Williams (2007) are among those who analyse the unemployment gap in the context of the Taylor Rule.

The three alternative measures of the output gap are compared in Figure 2, the unemployment gap generally appears to be negatively correlated with both measures of the output gap and of smaller magnitude; in most instances, a positive output gap is associated with a negative, albeit smaller, unemployment gap and vice versa. Given Okun's law (1962), this relationship is not unexpected. In comparing both measures of the output gap, indicates that, in most cases, the linear trend output gap was of a larger magnitude than the HP filter output gap. This was particularly evident between 1996Q1 and 2000Q2, where the linear

\footnotetext{
${ }^{9}$ See for example: Kam (2007), Stock and Watson (2003) and Nikolsko-Rzhevskyy (2011) and in the context of Australian data, Björksten et al. (2004), de Brouwer and Gilbert (2005), and Karagedikli and Lees (2007).

${ }^{10}$ For example, the $1994 \mathrm{Q} 1$ value for potential output is obtained by applying a standard two-sided HP filter to the real GDP series to an extended sample 1971Q2 to 1994Q1 and retaining the final observation of the filtered series. Sample length is then extended by one period and the process repeated to obtain all other potential real GDP estimates from 1994Q2 to 2013Q1.
} 
output was on average $1.52 \%$ and $1.49 \%$ larger than the HP filter output gap for the current vintage and real-time vintage respectively.

Furthermore, although both output gap series generally move together, between 1994Q1 and 1995Q2, there were multiple quarters in which one output gap displayed a positive change while the other measure of output gap exhibited a negative change. More recently, between 2011Q3 and 2013Q1, the linear trend output gap remained negative while the HP filter output gap was persistently positive. Overall, this analysis indicates that output gap estimation, and by extension, Taylor Rule recommendations, is sensitive to the output gap estimation method used. This conclusion supports the findings of de Brouwer (1998).

\section{Data}

The data use in this study is quarterly from 1994Q1 to 2013Q1.The starting period is dictated by the period in which the RBA officially acknowledge the target of inflation between two and three percent in Australia. ${ }^{11}$ Real-time seasonally adjusted real GDP data, were obtained from the Australian Real-Time Macroeconomic Database. The real-time real GDP series is created from the diagonal elements of the real GDP matrix that consists of all available vintages for each observation. Data descriptions, sources and transformation procedures are described in detail in Appendix A. Data used in Equation 1 to 4 is assumed to be stationary. The Augmented Dickey-fuller test and the Kwiatkowski-Phillips-SchmidtShin test for the data used in the Taylor rule are presented in in Appendix B. All data is available from the author.

\footnotetext{
${ }^{11}$ See for example Macfarlane (1998).
} 


\section{Methodology}

5.1 Step 1: The estimation of the Taylor Rule

Consider the following Taylor Rule with interest rate smoothing partial adjustment parameters:

$$
i_{t}=\delta+\left(1+\beta_{\pi}\right) \bar{\pi}_{t-1}+\beta_{y} y_{t-1}^{g a p}+\rho_{1} i_{t-1}+\rho_{2} i_{t-2}+\varepsilon_{t}
$$

where $\rho_{1}$ and $\rho_{2}$ are the partial adjustment parameters. Equation 3 is then estimated using OLS. For robustness, we combine nine possible estimations of Equation 3 using: three measures of inflation (headline, trimmed mean and weighted median CPI) and three different measure of output gap (linear detrended, Hodrick-Prescott (HP) filter output gap and unemployment gap). Following Clarida et al. (2000), Bunzel and Enders (2010), and Alcidi et al. (2011), two lags of the cash rate target were included, as this was found to be sufficient to remove any serial correlation from the residuals.

\subsection{Step 2: Factor augmented analysis}

Stock and Watson (2002), in the context of forecasting macroeconomic variables, introduce the use of principal component analysis to construct a small number of factors from a large set of macroeconomic time series that are then applied to a linear model. Bernanke and Boivin (2003) and Bernanke et al. (2005) assert that this methodology is particularly advantageous in the context of monetary policy analysis, as it allows policy reaction functions to be estimated that reflect the data-rich environment that central banks operate in. To be precise, the large number of economic and financial series monitored by central banks can be reflected in parsimonious models that are feasible to estimate. 
Consequently, a large macroeconomic data set of 229 series was collated, comprising 13 distinct international and domestic categories of variables representative of different sectors of the Australian economy. ${ }^{12}$ Although similar to the data sets of those authors, the analysis of a SOE like Australia warranted a particular focus on collating international series. These categories are: building approvals, changes in inventories, commodity prices, consumption, domestic interest rates, employment, foreign exchange rates, international interest rates, monetary and credit aggregates, price indexes, real output and income, retail trade and stock prices. ${ }^{13}$

To determine the number of factors that were formed using principal components from each category of variables, a relatively new criterion, the Eigenvalue Ratio Test (ERT), proposed by Ahn and Horenstein (2013), was implemented. The advantage of this criterion is that it is intuitive, demonstrates superior finite sample properties and does not rely upon as strict a set of assumptions as other similar criteria, including Bai and $\mathrm{Ng}$ (2002) and Onatski (2010). Upon implementing the ERT for each category of variables, one principal component estimated factor was retained for all categories, except in the case of commodity prices, international interest rates and stock prices, for which two principal component estimated factors were retained. The results of the ERT for each category of variables appear in Appendix C.

Following De Brouwer and Gilbert's (2005) acknowledgement of the significance of US monetary policy conduct on the RBA's policy decisions. An additional independent variable was considered - the US' deviation from its own Taylor Rule, estimated using a real-

\footnotetext{
${ }^{12}$ Please consult Appendix A for data description.

${ }^{13}$ Note that prior to factor extraction, following Stock and Watson (2002), all series were subject to possible transformation to induce stationarity, subsequent standardisation such that each series was zero mean and unit variance and lastly, screened for outliers. In contrast to Stock and Watson (2002) and Bernanke et al. (2005), who estimate factors using all series, in this investigation, principal component analysis using normalised loadings was used to extract factors from the 13 individual categories.
} 
time HP filter output gap and the GDP price deflator to calculate inflation. ${ }^{14}$ Using some of the estimated principal components, the following was estimated using OLS:

Taylor Rule deviation $_{t}=\delta+\beta_{1}$ USDEV $_{t}+\beta_{2}$ DOMIR $_{t}+\beta_{3}$ INTIR $_{t}+\beta_{4}$ COMM $_{t}+$

$$
\beta_{5} E X R A T E_{t}+\varepsilon_{t}, t=1,2, \ldots, T
$$

where $U S D E V_{t}$ is the deviation of the Taylor Rule in the US, DOMIR $R_{t}$ is the first principal component estimated factor of the domestic interest rate group, INTIR $R_{t}$ is the first principal component estimated factor of the international interest rate group, $C O M M_{t}$ is the first principal component estimated factor of the commodities group, EXRATE $E_{t}$ is the first principal component estimated factor of the exchange rate group, $\varepsilon_{t}$ is the assumed zero mean, i.i.d. error term.

\subsection{Step 3: The LMG-Shapley decomposition}

In order to quantify the explanatory power of the individual factors, the Lindeman, Merenda and Gold (LMG) (1980) - Shapley (1953) decomposition methodology is proposed in this step. ${ }^{15}$ Regarding this decomposition, Israeli (2007) notes that the individual contribution of an explanatory variable is determined by the unweighted average increase in $\mathrm{R}$-squared when that particular variable is added to the model for all $p$ ! possible model orderings. Grömping (2007) shows that the LMG - Shapley decomposition can be adapted in the OLS regression as:

$$
y_{t}=\beta_{0}+\sum_{j=1}^{p} \beta_{j} x_{t j}+\varepsilon_{t}, t=1,2, \ldots, T
$$

\footnotetext{
${ }^{14}$ Real-time GDP data for the US was obtained from the Real-Time Data Research Center, a part of the Research Department of the Federal Reserve Bank of Philadelphia.

${ }^{15}$ Note that this decomposition has been extensively applied in many fields including, but not limited to, statistics, psychology, physical and medical sciences, income distribution analysis, organisational behavior and game theory.
} 
where $y_{t}$ is the dependent variable at time $\mathrm{t}, x_{t j}, j=1,2, \ldots$, pare the independent variables at time $t$ and $\varepsilon_{t}$ is the assumed zero mean, i.i.d. error term, the coefficient of determination or Rsquared is given by:

$$
R_{\{1,2, \ldots, p\}}^{2}=\frac{\sum_{t=1}^{T}\left(\hat{y}_{t}-\bar{y}\right)^{2}}{\sum_{t=1}^{T}\left(y_{t}-\bar{y}\right)^{2}}
$$

where $\hat{y}_{t}$ are the fitted values of $y_{t}$ and $\bar{y}$ is the sample mean of $y_{t}$. Accordingly, the average $\mathrm{R}$-squared for $x_{t 1}$ over all possible orderingsis given by:

$$
\begin{aligned}
\bar{R}_{x_{t 1}}^{2} & =\frac{1}{p !} \sum_{S \subseteq\{2, \ldots, p\}} n(S) !(p-n(S)-1) !\left(R^{2}(\{1\} \cup S)-R^{2}(S)\right) \\
& =\frac{1}{p !} \sum_{S \subseteq\{2, \ldots, p\}} n(S) !(p-n(S)-1) ! \Delta R^{2}(\{1\} \mid S)
\end{aligned}
$$

where $S$ denotes the set of explanatory variables that are added to the model prior to $x_{t 1}$, $n(S)$ denotes the number of variables in the set of explanatory variables that are added to the model prior to $x_{t 1}, R^{2}(\{1\} \cup S)$ denotes the R-squared of a model containing both $S$ and $x_{t 1}$, $R^{2}(S)$ denotes the R-squared of a model containing $S$ and $\Delta R^{2}(\{1\} \mid S)$ denotes the increase in R-squared from adding $x_{t 1}$ to a model containing $S$. This same methodology is also used to compute $\bar{R}_{x_{t j}}^{2}, j=2, \ldots, p$. Note that $\bar{R}_{x_{t j}}^{2}$ represents the proportion of total variation in the dependent variable accounted for a by a particular explanatory variable. Similarly, $\bar{R}_{x_{t j}}^{2}$ can also be expressed as a proportion of the explained variation in the dependent variable by dividing each $\bar{R}_{x_{t j}}^{2}$ by the R-squared of the full model containing $x_{t j}, j=1,2, \ldots, p$ :

$$
\bar{R}_{x_{t j}}^{{ }^{*}}=\frac{\bar{R}_{x_{t j}}^{2}}{R_{\{1,2, \ldots, p\}}^{2}}
$$


Shorrocks (2013) argues that the advantages of the LMG - Shapley decomposition is that this method is an intuitive, exact additive composition of R-squared, meaning that the sum of the average, over all orderings, R-squared values of all explanatory variables will be equal to the R-squared of the regression containing all explanatory variables:

$$
R_{\{1,2, \ldots, p\}}^{2}=\sum_{j=1}^{p} \bar{R}_{x_{t j}}^{2}
$$

Secondly, given R-squared is an increasing function of the number of explanatory variables, a variable's contribution to the explained variation of the dependent variable cannot be negative.

\section{Empirical results}

6.1 The estimation of the Taylor Rule results

Table 1 shows that for all nine estimations, the estimate of $\beta_{\pi}$ is less than the 0.5 postulated by Taylor (1993) at 1\% of significance. Similarly, all output gap coefficients, while positive and statistically different from zero, are significantly less than 0.5 at $1 \%$ level significance. The three estimated unemployment gap coefficients, although negative and statistically different from zero, are much smaller than what is proposed by the Taylor Rule and Okun's law. Indeed, all three of the unemployment gap coefficients are statistically different from -1.25 at a $1 \%$ level of significance. The sum of the interest rate smoothing parameters is highly significant and also similar for all nine estimations; all values falling within a range of 0.83 to 0.85 . This suggests that the RBA has historically smoothed the target cash rate substantially. ${ }^{16}$

\footnotetext{
${ }^{16}$ Following Karagedikli and Lees (2007), general methods of moments is used to estimate a forward-looking variant where the cash rate is regressed on expectations of the contemporaneous value of inflation and the output gap. The set of instruments, as used by Karagedikli and Lees (2007), is three lags each of the cash rate target, the inflation rate and the output gap. This approach produces comparable results to those shown in Table 1. Kendall and $\mathrm{Ng}$ (2013) note that the underlying relationships between Taylor Rule variables may have changed since the GFC. Accordingly, Equation 3 is re-estimated after the inclusion of a dummy variable that,
} 
Figure 3a illustrates the cash rate target and the fitted Taylor Rule interest rate using the HP filter output gap and trimmed mean inflation and the difference between those two series. This estimation is taken as a benchmark as this rule produced the lowest sum of squared residual amongst the nine possible combinations. In figure $3 \mathrm{~b}$, the deviation is calculated as the historical cash rate target minus the Taylor Rule prescribed rate.

In both figures, is observed that the deviation from the actual cash rate target is generally very small; the maximum deviation occurring in 2008Q4, where the Taylor Rule prescribed rate was $6.74 \%$ compared to cash rate target of $5.28 \%$, implying a deviation of $1.45 \%$. This large deviation can be attributed to the RBA conducting pre-emptive expansionary monetary policy due to the deterioration of global economic conditions and strain on world financial markets; this assertion is supported by RBA's Statement on Monetary Policy released in November 2008 (Reserve Bank of Australia 2008). After 2011Q3, Taylor Rule implied interest rates have been persistently greater than the cash rate target, which is indicative of an accommodative policy regime by the RBA between 2011Q4 and 2013Q1. Loose monetary policy since 2011Q4 may be attributable to the RBA endeavouring to promote economic activity while focusing somewhat less on inflation. This is supported by Chevapatrakul and Paez-Farrell (2014), who note that following the GFC, central banks, including Australia's, have demonstrated a more flexible mandate in which output stabilisation is emphasised.

\subsubsection{Robustness analysis}

following Kendall and Ng (2013), is set equal to zero for all periods between 1994Q1 and 2008Q2 inclusive, and equal to one from period $2008 \mathrm{Q} 3$ onwards. The results of these re-estimations are available upon request but can be summarised by stating that the only significant change from the results contained in Table 1 is that the output gap coefficient is not statistically different from zero at a 5\% level of significance for all estimations using the HP filter and liner trend output gap. 
The robustness of calibrated Taylor Rule implied short-term interest rates to alternative measures of inflation and the output gap is then analysed in an Australian context. This is achieved by calculating the Taylor Rule interest rates using Equation 3 for each of the three measures of inflation, and for each of the three measures of the output gap previously considered. For each inflation measure, the equilibrium real interest rate used was the series that was calculated using that measure. Accordingly, nine alternative calibrated Taylor Rule recommendations were calculated, and the range of these recommendations in each quarter is illustrated in Figure 4, along with the cash rate target. If the range of these recommendations is narrow (wide), the more (less) robust the rule is to alternative measures of inflation and output gap measure.

The narrowest range of $0.33 \%$ occurs in $2002 \mathrm{Q} 2$, the widest range of $3.48 \%$ occurs in 2009 Q4, and the average range is equal to $1.48 \%$. Upon inspection of Figure 4, it appears that generally, the cash target has fallen within the range of implied Taylor Rule interest rates throughout the sample period. One particular point of note that is illustrated in Figure 4 is the aggressive pre-emptive response of the RBA to the GFC in 2008. Between 2008Q3 and 2009Q2, the average cash rate target decreased by 415 basis points and appears to have preempted the negative output gap induced decrease in implied Taylor Rule interest rates by approximately two quarters. Figure 4 also indicates that since the GFC, the interest rate implied by the Taylor Rule has generally been consistently lower than the cash rate target.

\subsection{Determinants of the deviations of the Taylor Rule-Results}

In Table 2 all nine possible combination of the Taylor Rule previously described are shown. ${ }^{17}$ The R-squared value of all estimation varies between $61 \%$ and $68 \%$ showing significant explanation power. All factors specified in Equation 4 are statistically significant

\footnotetext{
${ }^{17}$ Note that the inclusion of a lagged dependent variable term in Equation 4 was found to be highly insignificant.
} 
at conventional levels in all equations, with the exception of the commodities factor when Taylor Rule deviation is obtained from estimations that use the linear trend output gap, which are significant at a $15 \%$ level of significance. The US' deviation from its Taylor Rule, the domestic interest rate factor, and the exchange rate factor are highly significant for all alternative measures of the output gap and the inflation rate.

\subsection{LMG - Shapley decomposition-Results}

In Table 3, results from the LMG - Shapley decomposition of Equation 4 is presented. This table shows that for the commodities factor, the average R-squared value of $12.5 \%$ means that $12.5 \%$ of the total variation in deviation from the Taylor Rule is explained by the commodity factor. Similarly, $19.4 \%$ of the explained variation in deviation from the Taylor Rule is accounted for by the commodity factor. Analogous interpretations can be made for all other repressors in Equation 4. Of note, $34.9 \%$ and $13.3 \%$ of the explained variation in deviation from the Taylor Rule is accounted for by the estimated factor of the domestic interest rate and the US' deviation from the Taylor Rule, respectively. International factors seemingly account for $(0.125+0.160+0.048+0.086)=41.9 \%$ of the total variation in deviation from the Taylor Rule. Furthermore, the only domestic factor in Equation 4, the estimated factor of domestic interest rates, explains $22.5 \%$ of the total variation in deviation from the Taylor Rule.

\section{Conclusion}

In this investigation we developed an innovative three-step econometric procedure to analyse and quantify monetary policy deviations from the Taylor Rule. While we have applied this methodology to a small open economy such as Australia, application of this 
procedure to other economies with inflation targeting monetary rule is also valid. The Taylor Rule was firstly estimated using OLS. Secondly, the residual from the this estimation, representing Australia's deviation from the Taylor Rule was explained using a number of international and domestic factors, extracted from a large data set using principal components. Specifically, 229 macroeconomic series from 13 categories were compressed into a small number of factors. The final step in the methodology involved applying the LMG - Shapley decomposition methodology to decompose the explanatory power of the estimated factors.

The primary findings are that approximately $65 \%$ of Australia's deviation in the Taylor Rule can be explained systematically, with international factors and a domestic factor accounting for $41.9 \%$ and $22.5 \%$ of the total variation in deviation from the rule, respectively. The sole domestic factor, domestic interest rates other than the cash rate, accounts for $22.5 \%$ of the total variation in deviation from the Taylor Rule. Other domestic factors, including employment, real output and income other than real GDP, and other prices in the economy are found not to be systematic in explaining deviation from the rule. The international factors that account for Australia's Taylor Rule deviation are exchange rates, commodity prices, the US' deviation from its estimated Taylor Rule and international interest rates explaining 16, 12.5, 8.6 and 4.8\% of the total variation in Australia's deviation from the Taylor Rule, respectively. Importantly, the conclusion that can be drawn from the significance of the US' deviation is that Australia appears to be following an international monetary policy trend set forth by the world's largest economy. 


\section{References}

Ahn, SC \& Horenstein, AR 2013, 'Eigenvalue ratio test for the number of factors', Econometrica, vol. 81, no. 3, pp. 1203-1227.

Alcidi, C, Flamini, A \& Fracasso, A 2011, 'Policy regime changes, judgment and Taylor rules in the Greenspan era', Economica, vol. 78, no. 309, pp. 89-107.

Asso, PF, Kahn, GA \& Leeson, R 2007, 'The Taylor rule and the transformation of monetary policy', Research Working Paper, no.07-11, Federal Reserve Bank of Kansas City.

Bai, J \& Ng, S 2002, 'Determining the number of factors in approximate factor models', Econometrica, vol. 70, no. 1, pp. 191-221.

Berg, C, Jansson, P \& Vredin, A 2004, 'How useful are simple rules for monetary policy? The Swedish experience', Working Paper Series, no. 169,Sveriges Riksbank.

Bernanke, BS \&Boivin, J 2003, 'Monetary policy in a data-rich environment', Journal of Monetary Economics, vol. 50, no. 3, pp. 525-546.

Bernanke, BS, Boivin, J \& Eliasz, P 2005, 'Measuring the effects of monetary policy: a factor-augmented vector autoregressive (FAVR) approach', Quarterly Journal of Economics, vol. 120, no. 1, pp. 387-422.

Bernanke, BS \& Gertler, M 1999, 'Monetary policy and asset price volatility', Economic Review, Federal Reserve Bank of Kansas City, vol. 84, no. 4, pp. 17-51.

Björksten, N, Karagedikli, Ö, Plantier, C \& Grimes, A 2004, 'What does the Taylor rule say about a New Zealand-Australia currency union?', The Economic Record, vol. 80, supplement, pp. S34-S42.

Breusch, TS 1978, 'Testing for autocorrelation in dynamic linear models', Australian Economic Papers, vol. 17, no. 31, pp. 334-355.

de Brouwer, G \& Gilbert, J 2005, 'Monetary policy reaction functions in Australia', TheEconomic Record, vol. 81, no. 253, pp. 124-134.

de Brouwer, G \& O'Regan, J 1997, 'Evaluating simple monetary-policy rules for Australia', in P Lowe (ed.), Monetary policy and inflation targeting, Reserve Bank of Australia, Sydney, pp. 244-276.

Bunzel, H \& Enders, W 2010, 'The Taylor rule and "opportunistic" monetary policy', Journal of Money, Credit and Banking, vol. 42, no. 5, pp. 931-949.

Castelnuovo, E 2003, 'Taylor rules, omitted variables, and interest rate smoothing in the US', Economics Letters, vol. 81, no. 1, October 2003, pp. 55-59.

Castelnuovo, E 2007, 'Taylor Rules and interest rate smoothing in the Euro area', The Manchester School, vol. 75, no. 1, pp. 1-16.

Cecchetti, SG, Hooper, P, Kasman, BC, Schoenholtz, KL \& Watson, MW 2007, 'Understanding the evolving inflation process', paper presented at the U.S. Monetary Policy 
Forum, Washington, 9 March, viewed 22 September 2014, <http://research.chicagobooth.edu/igm/docs/2007usmpf-report.pdf >.

Chevapatrakul, T \& Paez-Farrell, J 2014, 'Monetary policy reaction functions in small open economies: a quantile Regression Approach', Manchester School, vol. 82, no. 2, pp. 237256.

Clarida, R, Gali J \& Gertler, M 2000, 'Monetary policy rules and macroeconomic stability: evidence and some theory', Quarterly Journal of Economics, vol. 115, no. 1, pp. 147-180.

English, W, Nelson, W \& Sack, B 2003, 'Interpreting the significance of the lagged interest rate in estimated monetary policy rules', Contributions to Macroeconomics, vol. 3, no. 1, pp. 1073-1089.

Godfrey, LG 1978a, 'Testing against general autoregressive and moving average error models when the regressors include lagged dependent variables', Econometrica, vol. 46, no. 6, pp. 1293-1301.

Godfrey, LG 1978b, 'Testing for higher order serial correlation in regression equations when the regressors include lagged dependent variables', Econometrica, vol. 46, no. 6, pp. 13031310 .

Goodfriend MS 1987, 'Interest rate smoothing and price level trend-stationarity', Journal of Monetary Economics, vol. 19, no. 3, pp. 335-348.

Grömping, U 2007, 'Estimators of relative importance in linear regression based on variance decomposition', American Statistician, vol. 61, no. 2, pp. 139-147.

Israeli, O 2007, 'A Shapley-based decomposition of the R-square of a linear regression', Journal of Economic Inequality, vol. 5, no. 2, pp. 199-212.

Hodrick, RJ \& Prescott, EC 1997, 'Postwar U.S. business cycles: an empirical investigation', Journal of Money, Credit and Banking, vol. 29, no. 1, pp. 1-16.

Kahn, GA 2010, 'Taylor rule deviations and financial imbalances', Economic Review, Federal Reserve Bank of Kansas City, vol. 95, no. 2, pp. 63-99.

Kahn, GA 2012, 'Estimated rules for monetary policy', Economic Review, Federal Reserve Bank of Kansas City, vol. 97, no. 4, pp. 5-29.

Kam, T 2007, 'Interest-rate smoothing in a two-sector small open economy', Journal of Macroeconomics, vol. 29, no. 2, pp. 283-304..

Karagedikli, Ö\& Lees, K 2007, 'Do the central banks of Australia and New Zealand behave asymmetrically? Evidence from monetary policy reaction functions', The Economic Record, vol. 83, no. 261, pp. 131-142.

Kendall, R \& Ng, T 2013, 'Estimated Taylor rules updated for the post-crisis period', Reserve Bank of New Zealand Analytical Note series, no. AN2013/04, Reserve Bank of New Zealand. 
Kozicki, S 1999, 'How useful are Taylor rules for monetary policy?', Economic Review, Federal Reserve Bank of Kansas City, vol. 84, no. 2, pp. 5-33.

Kwiatkowski, D, Phillips, PCB, Schmidt, P \& Shin, Y 1992, 'Testing the null hypothesis of stationarity against the alternative of a unit root: how sure are we that economic time series have a unit root?', Journal ofEconometrics, vol. 54, no. 1-3, pp. 159-178.

Laxton, D \& Pesenti, P 2003, 'Monetary rules for small, open, emerging economies', Journal of Monetary Economics, vol. 50, no. 5, pp. 1109-1146.

Lee, KC, Morley, J \& Shields, K 2011, 'The meta Taylor rule', Working Paper, no. 11/07,Centre for Finance and Credit Markets.

Lee, KC, Olekalns, N \& Shields, K 2013, 'Meta Taylor rules for the UK and Australia; accommodating regime uncertainty in monetary policy analysis using model averaging methods', Manchester School, vol. 81, no. S3, pp. 28-53.

Lindeman, RH, Merenda, PF \& Gold, RZ 1980, Introduction to bivariate and multivariate analysis, Scott, Foresman and Company, Glenview, Illinois.

Lowe, P \& Ellis, L 1997, 'The smoothing of official interest rates', in P Lowe (ed.), Monetary policy and inflation targeting, Reserve Bank of Australia, Sydney, pp. 286-312.

Macfarlane 1998, 'Australian monetary policy in the last quarter of the twentieth century', Reserve Bank of Australia Bulletin, October, pp. 6-19.

Mehra, YP \& Minton, BD 2007, 'A Taylor rule and the Greenspan era', Economic Quarterly, Federal Reserve Bank of Richmond, vol. 93, no. 3, pp. 229-250.

Mehra, YP \& Sawhney, B 2010, 'Inflation measure, Taylor rules, and the GreenspanBernanke years', Economic Quarterly, Federal Reserve Bank of Richmond, vol. 96, no. 2, pp. $123-151$.

Newey, WK \& West, KD 1987, 'A simple, positive semi-definite, heteroskedasticity and autocorrelation consistent covariance matrix',Econometrica, vol. 55, no. 3, pp. 703-708.

Newey, WK \& West, KD 1994, 'Automatic lag selection in covariance matrix estimation', Review of Economic Studies, vol. 61, no. 4, pp. 631-653.

Nikolsko-Rzhevskyy, A 2011, 'Monetary policy estimation in real time: forward-looking Taylor rules without forward-Looking data' Journal of Money, Credit and Banking, vol. 43, no. 5, pp. 871-897.

Okun, AM 1962 'Potential GNP: its measurement and significance', Proceedings of the Business and Economics Statistics Section (American Statistical Association), pp. 98-104.

Onatski, A 2010, 'Determining the number of factors from empirical distribution of eigenvalues', Review of Economic and Statistics, vol. 92, no. 4, pp. 1004-1016.

Orphanides, A 2001, 'Monetary policy rules based on real time data', American Economic Review, vol. 91, no. 4, pp. 964-985. 
Pinkwart, P 2013, 'Quantifying the European Central Bank's interest rate smoothing behaviour', Manchester School, vol. 81, no. 4, pp. 470-492.

Reserve Bank of Australia 1995, 'Quarterly report on the economy and financial markets', Reserve Bank of Australia, October.

Reserve Bank of Australia 1997, 'Semi-Annual sstatement on monetary policy', Reserve Bank of Australia, November.

Reserve Bank of Australia 1998, 'Semi-Annual sstatement on monetary policy', Reserve Bank of Australia, November.

Reserve Bank of Australia 2000a, 'Semi-Annual sstatement on monetary policy', Reserve Bank of Australia, May.

Reserve Bank of Australia 2000b, 'Statement on monetary policy', Reserve Bank of Australia, November.

Reserve Bank of Australia 2006, 'Statement on monetary policy', Reserve Bank of Australia, August.

Reserve Bank of Australia 2008, 'Statement on monetary policy', Reserve Bank of Australia, November.

Reserve Bank of Australia 2009, 'Statement on monetary policy', Reserve Bank of Australia, November.

Reserve Bank of Australia 2011a, 'Statement on monetary policy', Reserve Bank of Australia, February.

Reserve Bank of Australia 2011b, 'Statement on monetary policy', Reserve Bank of Australia, May.

Richards, T \& Rosewall, T 2010, 'Measures of underlying inflation', Reserve Bank of Australia Bulletin, March.

Schwarz, G 1978, 'Estimating the dimension of a model', Annals of Statistics, vol. 6, no. 2, pp. 461-464.

Shapley, LS 1953, 'A value for n-person games', in HW Kuhn \& AW Tucker (eds), Contributions to the theory of games, vol. 2, Princeton University Press, Princeton, New Jersey, pp. 307-317.

Shorrocks, AF 2013, 'Decomposition procedures for distributional analysis: a unified framework based on the Shapley value', Journal of Economic Inequality, vol. 11, no. 1, pp. 99-126.

Stock, JH \& Watson, MW 2002, 'Macroeconomic forecasting using diffusion indexes', Journal of Business \& Economic Statistics, vol. 20, no. 2, pp. 147-162.

Stock, JH \& Watson, MW 2003, 'Forecasting output and inflation: the role of asset prices', Journal of Economic Literature, vol. 41, no. 3, pp. 788-829. 
Svensson, LEO 2003, 'What is wrong with Taylor rules? Using judgment in monetary policy through targeting rules', Journal of Economic Literature, vol. 11,no. 2, pp. 426-477.

Taylor, JB 1993, 'Discretion versus policy Rules in practice', Carnegie-Rochester Conference Series on Public Policy, vol. 39, pp. 195-214.

Taylor, JB 1999, 'A historical analysis of monetary policy rules', in JB Taylor (ed.), Monetary policy rules, University of Chicago Press, Chicago, Illinois, pp. 319-341.

Williams, JC 2003, 'Simple rules for monetary policy', Economic Review, Federal Reserve Bank of San Francisco, pp. 1-12.

Woodford, M 2003, 'Optimal interest-rate smoothing', Review of Economic Studies, vol. 70, no. 4, pp. $861-886$.

Wooldridge, JM 2009, Introductory econometrics, 4thedn, South-Western Cengage Learning, Mason, Ohio. 


\section{Appendix A - Data Description}

Transformation codes are as follows: 1 -no transformation, 2-first difference, 3 -natural logarithms, 4-first difference of natural logarithms, 5-second difference of natural logarithms. An asterisk (*) next to the transformation code indicates that the author aggregated the series from monthly to quarterly frequency series using the 3-month average. The following abbreviations appear in the data description: seasonally adjusted (SA), not seasonally adjusted (NSA), author calculations (ac), chain volume measure (CVM), Australian dollar (AUD), US dollar (USD), millions of Australian dollars (\$mil), billions of Australian dollars (\$bil), International Monetary Fund (IMF), Federal Reserve Bank of St. Louis (FRBSL), Organisation for Economic cooperation and Development (OECD), Standard and Poor's (S\&P), Australian Stock Exchange (ASX), Commodity Research Bureau (CRB), Datastream (DS), Thomson Reuters (TR), London Bullion Market (LBM), household final consumption expenditure (HFCE), final consumption expenditure (FCE), bank accepted bills (BAB), negotiable certificates of deposit (NCD), Special drawing right (SDR), aggregate monthly hours (AMH), per annum (pa), producer price index (PPI), Australian financial institutions (AFI), non-bank financial institutions (NBFI) and industrial production (IP). All values are in AUD unless otherwise stated. For all CVM series obtained from the ABS, the reference year is 2011-12. For series obtained from Datastream and the Federal Reserve Bank of St. Louis, series code appears in parentheses.

\section{A.1 Taylor Rule data}

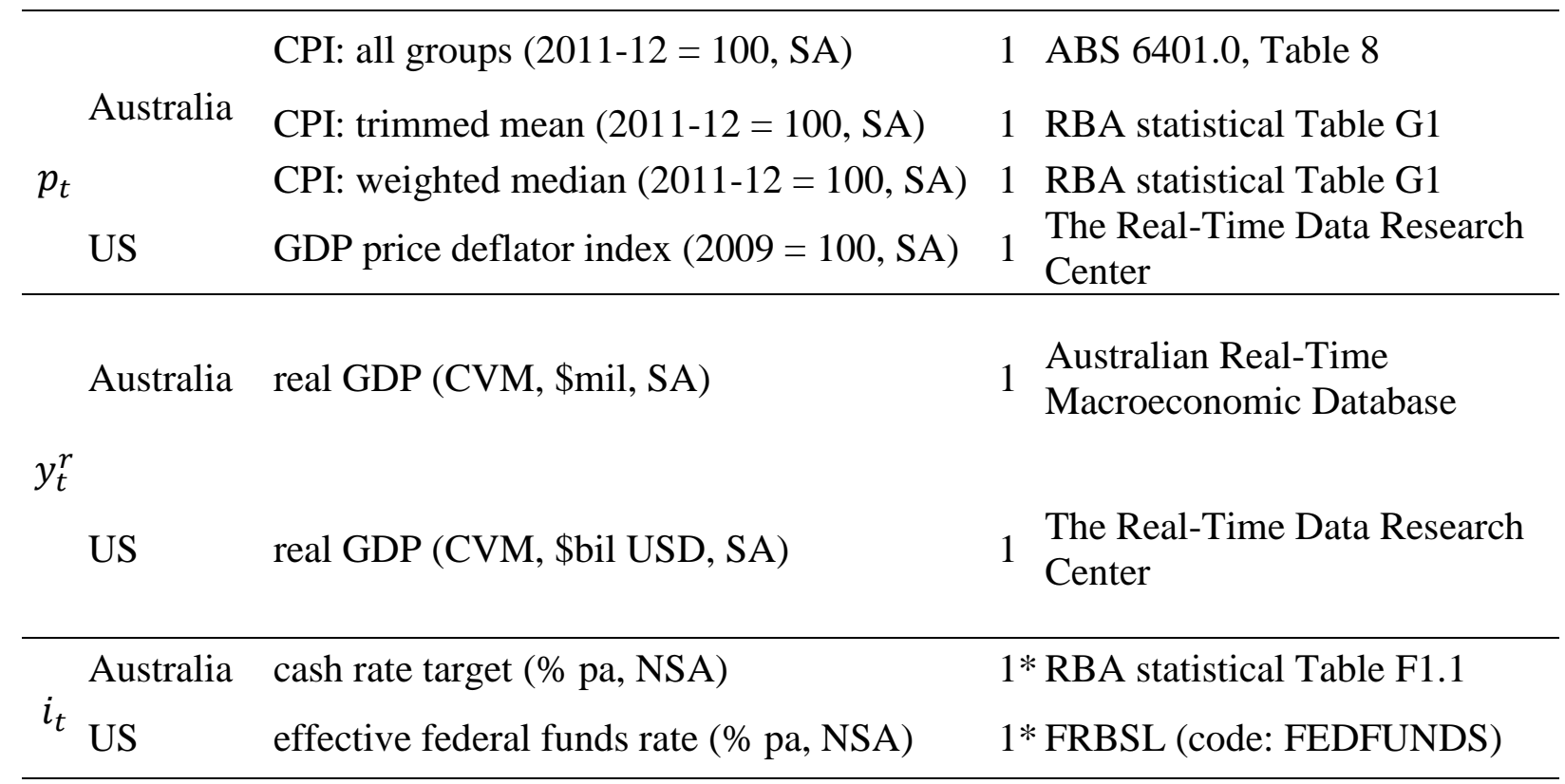

Notes: With respect to Australian real GDP, the first release observation for 1973Q2 in 1973Q3 vintage was missing and was replaced with observation for 1973Q2 in 1973Q4 vintage. With respect to the US real GDP, the first release observation for 1995Q4 in 1996Q1 vintage was missing and was replaced with observation for 1995Q4 in 1996Q2 vintage. 


\section{A.2 Principal component data}

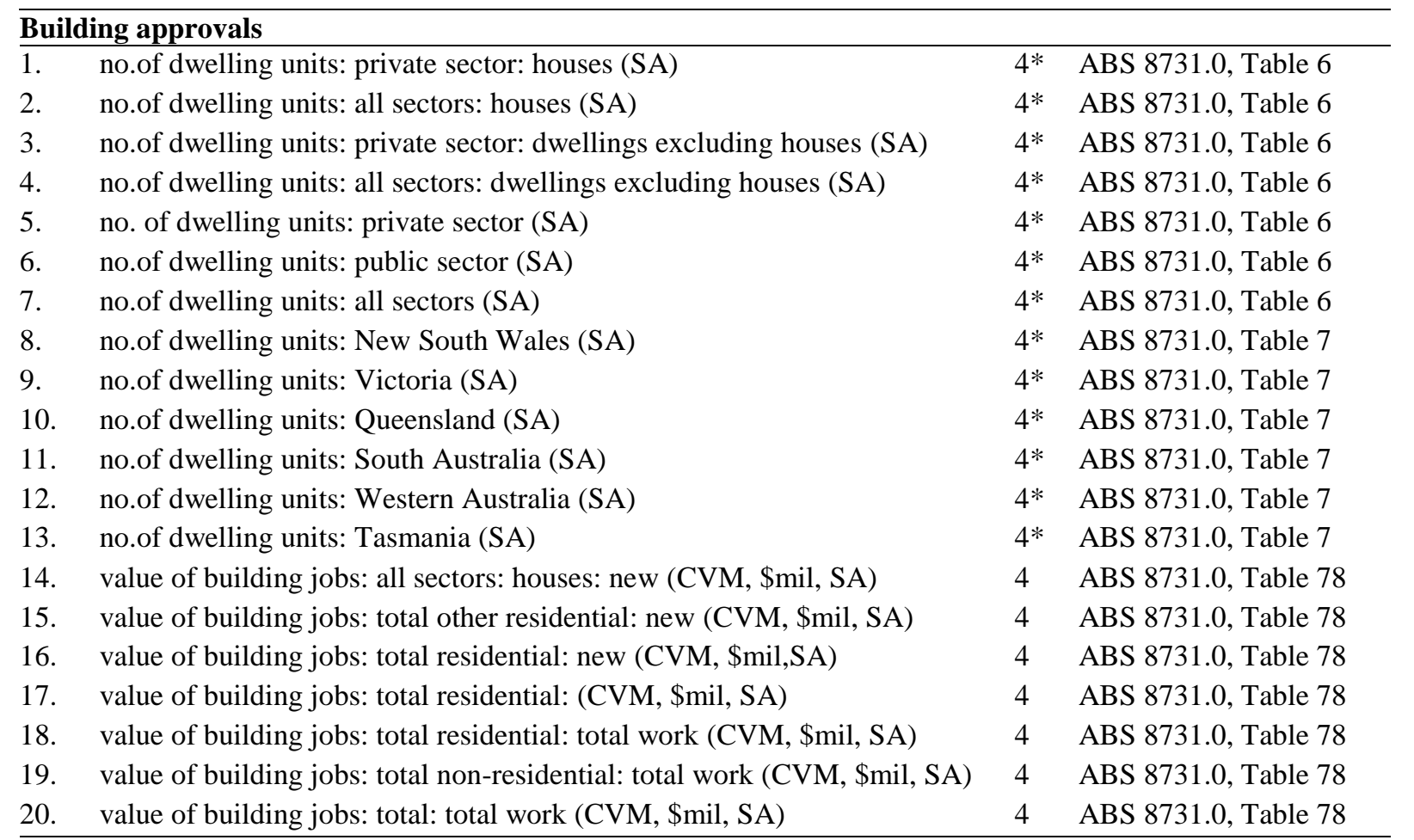

\begin{tabular}{ll}
\hline Changes in inventories \\
\hline 1. & changes in inventories (CVM, \$mil, SA) \\
2. & changes in inventories: private: manufacturing (CVM, \$mil, SA) \\
3. & changes in inventories: private: wholesale trade (CVM, \$mil, SA) \\
4. & changes in inventories: private: retail trade (CVM, \$mil, SA) \\
5. & changes in inventories: private: non-farm (CVM, \$mil, SA) \\
6. & changes in inventories: farm (CVM, \$mil, SA) \\
7. & changes in inventories: public authorities (CVM, \$mil, SA)
\end{tabular}

\section{Commodity prices}

1. commodity prices: all items index $(2012-13=100$, NSA)

2. commodity prices: all items index (SDR, 2012-13 = 100, NSA)

3. commodity prices: all items index (USD, 2012-13 = 100, NSA)

4. commodity prices: rural items index $(2012-13=100$, NSA)

5. commodity prices: rural items index (SDR, 2012-13 = 100, NSA)

6. commodity prices: rural items index (USD, 2012-13 = 100, NSA)

7. commodity prices: non-rural items index (2012-13 = 100, NSA)

8. commodity prices: non-rural items index (SDR, 2012-13 = 100, NSA)

9. commodity prices: non-rural itemsindex (USD, 2012-13 = 100, NSA)

10. commodity prices: non-rural items: base metals index $(2012-13=100$, NSA)

11. commodity prices: base metals index (SDR, 2012-13 = 100, NSA)

12. commodity prices: base metals index (USD, 2012-13 = 100, NSA)

13. commodity prices: bulk commodities index $(2012-13=100$, NSA $)$

14. commodity prices: bulk commodities index (SDR, 2012-13 =100, NSA)

15. commodity prices: bulk commodities index (USD, 2012-13 =100, NSA)

16. S\&P - Goldman Sachs total return commodity index $(\mathrm{USD}, 1970=100$, NSA)

17. TR equal weight continuous commodity index (USD, $1967=100$, NSA)

1 ABS 5206.0, Table 9

1 ABS 5206.0, Table 9

1 ABS 5206.0, Table 9

1 ABS 5206.0, Table 9

1 ABS 5206.0, Table 9

1 ABS 5206.0, Table 9

1 ABS 5206.0, Table 9

\section{4* $\quad$ RBA statistical Table I2}

4* RBA stat. Table I2

4* RBA stat. Table I2

4* RBA stat. Table I2

4* RBA stat. Table I2

4* RBA stat. Table I2

4* RBA stat. Table I2

4* RBA stat. Table I2

4* RBA stat. Table I2

4* RBA stat. Table I2
RBA stat. Table I2 RBA stat. Table I2 RBA stat. Table I2 RBA stat. Table I2 RBA stat. Table I2 S\&P via DS(GSCITOT)

TR via DS (NYFECRB) 
18. CRB spot index (USD, $1967=100$, NSA)

19. CRB spot: foodstuffs index (USD, $1967=100$, NSA)

20. CRB spot: fats and oils index (USD, $1967=100$, NSA)

21. CRB spot: livestock index (USD, $1967=100, \mathrm{NSA})$

22. CRB spot: metals index (USD, $1967=100$, NSA)

23. CRB spot: raw industrials index (USD, $1967=100$, NSA)

24. CRB spot: textiles index (USD, $1967=100$, NSA)

25. Crude oil price (USD per barrel, NSA)

26. Gold bullion price (UK pounds per troy ounce, NSA)

Consumption
$1 . \quad$ HFCE: total (CVM, \$mil, SA)

2. HFCE: food (CVM, \$mil, SA)

3. HFCE: cigarettes and tobacco(CVM, \$mil, SA)

4. HFCE: alcoholic beverages(CVM, \$mil, SA)

5. HFCE: clothing and footwear(CVM, \$mil, SA)

6. HFCE: rent and other dwelling services(CVM, \$mil, SA)

7. HFCE: electricity, gas and other fuel(CVM, \$mil, SA)

8. HFCE: furnishings and household equipment(CVM, \$mil, SA)

9. HFCE: health(CVM, \$mil, SA)

10. HFCE: purchase of vehicles(CVM, \$mil, SA)

11. HFCE: operation of vehicles(CVM, \$mil, SA)

12. HFCE: transport services(CVM, \$mil, SA)

13. HFCE: communications(CVM, \$mil, SA)

14. HFCE: recreation and culture(CVM, \$mil, SA)

15. HFCE: education services(CVM, \$mil, SA)

16. HFCE: hotels, cafes and restaurants(CVM, \$mil, SA)

17. HFCE: insurance and other financial services(CVM, \$mil, SA)

18. HFCE: other goods and services(CVM, \$mil, SA)

19. FCE: general government - national (CVM, \$mil, SA)

20. FCE: general government - state and local (CVM, \$mil, SA)

21. FCE: general government (CVM, \$mil, SA)

22. FCE: all sectors (CVM, \$mil, SA)

\section{Domestic interest rates}

1. 30-day BAB/NCD (\% pa, NSA)

2. 90 -day BAB/NCD (\% pa, NSA)

3. $180-\mathrm{BAB} / \mathrm{NCD}(\%$ pa, NSA)

4. Government 5-year bond yield (\% pa, NSA)

5. Government 10 -year bond yield ( $\%$ pa, NSA)

6. spread: 30-day $\mathrm{BAB} / \mathrm{NCD}$ - cash rate target

7. spread: 90-day $\mathrm{BAB} / \mathrm{NCD}$ - cash rate target

8. spread: 180 -day $\mathrm{BAB} / \mathrm{NCD}$ - cash rate target

9. spread: Government 5-year bond yield - cash rate target

10. spread: Government 10 -year bond yield - cash rate target

\section{Employment}

1. employed persons (thousands, SA)

2. employed persons: full-time (thousands, SA)

3. employed persons: part-time (thousands, SA)

4. labour force (thousands, SA)

5. labour force participation rate $(\%, \mathrm{SA})$

6. employment to population ratio $(\%, \mathrm{SA})$

7. unemployment rate $(\%, \mathrm{SA})$

8. underemployment rate $(\%, \mathrm{SA})$
4 CRB via DS(CRBSPOT)

$4 \quad$ CRB via DS (CRBSPFD)

4 CRB via DS (CRBSPFO)

4 CRB via DS(CRBSPLV)

4 CRB via DS(CRBSPMT)

4 CRB via DS(CRBSPRI)

4 CRB via DS(CRBSPTX)

4 DS(OILBRDT)

4 DS (GOLDBN£)

ABS 5206.0, Table 8
ABS 5206.0, Table 8
ABS 5206.0, Table 8
ABS 5206.0, Table 8
ABS 5206.0, Table 8
ABS 5206.0, Table 8
ABS 5206.0, Table 8
ABS 5206.0, Table 8
ABS 5206.0, Table 8
ABS 5206.0, Table 8
ABS 5206.0, Table 8
ABS 5206.0, Table 8
ABS 5206.0, Table 8
ABS 5206.0, Table 8
ABS 5206.0, Table 8
ABS 5206.0, Table 8
ABS 5206.0, Table 8
ABS 5206.0, Table 8
ABS 5206.0, Table 8
ABS 5206.0, Table 8
ABS 5206.0, Table 8
ABS 5206.0, Table 8

2* RBA Table F1.1

2* RBA Table F1.1

2* RBA Table F1.1

2* RBA Table F2

2* RBA Table F2

1 ac

1 ac

1 ac

1 ac

$1 \mathrm{ac}$ 
10. AMH worked: (thousands, SA)

11. AMH worked: full time employment (thousands, SA)

12. AMH worked: part time employment (thousands, SA)

13. AMH worked: agriculture sector (thousands, SA)

14. AMH worked: market sector excluding agriculture sector (thousands, SA) 4

15. AMH worked: market sector (thousands, SA)

16. AMH worked: education sector ((thousands, SA)

17. AMH worked: non market sector excluding education sector (thousands, SA)

18. AMH worked: non market sector (thousands, SA)

19. AMH worked: market sector and non-market sector (thousands, SA)

20. employees: agriculture, forestry and fishing (thousands, SA)

21. employees: mining (thousands, SA)

22. employees: manufacturing (thousands, SA)

23. employees: electricity, gas, water and waste services (thousands, SA)

24. employees: construction (thousands, SA)

25. employees: retail trade (thousands, SA)

26. employees: accommodation and food services (thousands, SA)

27. employees: transport, postal and warehousing (thousands, SA)

28. employees: information media and telecom. (thousands of persons, SA)

29. employees: financial and insurance services (thousands, SA)

30. employees: rental, hiring and real estate services (thousands, SA)

31. employees: professional, scientific and technical services (thousands, SA)

32. employees: administrative and support services (thousands, SA)

33. employees: public administration and safety (thousands, SA)

34. employees: education and training (thousands, SA)

35. employees: health care and social assistance (thousands, SA)

36. employed persons: arts and recreation services (thousands of persons, SA)

37. employees: other services (thousands of persons, SA)

38. employees: industrial sector including construction (thousands, SA)

39. employees: industrial sector excluding construction (thousands, SA)

40. employees: services sector (thousands, SA)

$1 \quad$ ABS 6202.0, Table 22

4* ABS 6202.0, Table 19

4* ABS 6202.0, Table 19

4* ABS 6202.0, Table 19

4 ABS 6202.0, Table 21

4 ABS 6202.0, Table 21

4 ABS 6202.0, Table 21

4 ABS 6202.0, Table 21

4 ABS 6202.0, Table 21

$4 \quad$ ABS 6202.0, Table 21

4 ABS 6202.0, Table 21

4 ABS 6291.0.55.003

4 ABS 6291.0.55.003

4 ABS 6291.0.55.003

4 ABS 6291.0.55.003

4 ABS 6291.0.55.003

4 ABS 6291.0.55.003

4 ABS 6291.0.55.003

4 ABS 6291.0.55.003

4 ABS 6291.0.55.003

4 ABS 6291.0.55.003

4 ABS 6291.0.55.003

4 ABS 6291.0.55.003

4 ABS 6291.0.55.003

4 ABS 6291.0.55.003

4 ABS 6291.0.55.003

4 ABS 6291.0.55.003

4 ABS 6291.0.55.003

4 ABS 6291.0.55.003

4 DS (AUQLF003O)

4 DS (AUQLF004O)

4 DS (AUQLF006O)

\section{Foreign exchange rates}

1. Japanese yen/AUD spot exchange rate (Japanese yen per AUD, NSA)

2. USD/AUD spot exchange rate (USD per AUD, NSA)

3. UK pound/AUD spot exchange rate (UK pounds per AUD, NSA)

4. SDR/AUD spot exchange rate (SDR per AUD, NSA)

5. AUD trade weighted index (May $1970=100$, NSA)

6. Swiss franc/AUD spot exchange rate (Swiss francs per AUD, NSA)

7. Chinese renminbi/AUD spot exchange rate (NSA)

8. Korean won/AUD spot exchange rate (Korean won per AUD, NSA) 1994Q1-1998Q4: Euro /AUD spot exchange rate (Euro /AUD, NSA) 1999Q1-2013Q1: Euro/AUD spot exchange rate (Euros per AUD, NSA)

\section{International interest rates}

1. US 3-month treasury bills (\% pa, NSA)

2. Canada 3-month treasury bills (\% pa, NSA)

3. Mexico 1-month treasury certificate (\% pa, NSA)

4. UK 3-month treasury bills (\% pa, NSA)

5. Spain 3-month treasury bills (\% pa, NSA)

6. France 3-month treasury bills (\% pa, NSA)

7. Italy 3-month treasury bills (\% pa, NSA)

\section{2* FRBSL}

2* FRBSL

2* FRBSL

2* FRBSL

2* FRBSL

2* FRBSL

2* FRBSL 
8. Japan 3-month treasury bills (\% pa, NSA)

9. US 1-year treasury constant maturity rate (\% pa, NSA)

10. US 3-year treasury constant maturity rate (\% pa, NSA)

11. US 5-year treasury constant maturity rate (\% pa, NSA)

12. US 10-year treasury constant maturity rate (\% pa, NSA)

13. US 20-year treasury constant maturity rate (\% pa, NSA)

14. Moody's seasoned Aaa corporate bond yield ( $\%$ pa, NSA)

15. Moody's seasoned Baa corporate bond yield (\% pa, NSA)
2* FRBSL

2* FRBSL (GS1)

2* FRBSL (GS3)

2* FRBSL (GS5)

2* FRBSL (GS10)

2* FRBSL (GS20)

$2 *$ FRBSL (AAA)

2* FRBSL (BAA)

\section{Monetary and credit aggregates}

1. current deposits with banks (current prices, \$bil, SA) 4

* RBA stat. Table D3

2. deposits with non-bank authorised deposit-taking (current prices, \$bil, SA) 4*

3. other borrowings from private sector by AFI (current prices, \$bil, SA)

4. currency: holdings of notes by the private sector (current prices, \$bil, SA)

5. money stock: M1 (current prices, \$bil, SA)

6. money stock: M3 (current prices, \$bil, SA)

7. broad money (current prices, \$bil, SA)

8. monetary base (current prices, \$bil, SA)

9. loans and advances: banks - excludes secur. (current prices, \$bil, SA)

$5 *$

$4 *$

11. loans and advances; AFI - excludes securitisations (current prices, \$bil, SA) $5^{*}$

12. bills on issue (current prices, \$bil, SA)

13. narrow credit- excludes securitisations (current prices, \$bil, SA)

14. credit: total - includes securitisations (current prices, \$bil, SA)

15. credit: owner-occupier housing - includes secur. (current prices, \$bil, SA)

16. credit: investor housing - includes (current prices, \$bil, SA)

17. credit: other personal - includes securitisations (current prices, \$bil, SA)

18. credit: business - includes securitisations (current prices, \$bil, SA)

19. lending to the government sector by AFI (current prices, \$bil AUD, NSA)

20. total holdings of official reserve assets (current prices, \$mil, NSA)

\section{Price indexes}

1. CPI: food and non-alcoholic beverages (2011-12 = 100, SA by author)

2. CPI: alcohol and tobacco $(2011-12=100$, SA by author $)$

3. CPI: clothing and footwear (2011-12 = 100, SA by author)

4. CPI: housing (2011-12 =100, SA by author)

RBA stat. Table A4
5. CPI: furnishings, household equip. and serv. $(2011-12=100$, SA by author) 4

6. CPI: health $(2011-12=100$, SA by author $)$

7. CPI: transport (2011-12 $=100$, SA by author $)$

8. CPI: communication (2011-12 $=100$, SA by author)

9. CPI: recreation and culture $(2011-12=100$, SA by author)

10. CPI: education (2011-12 $=100$, SA by author)

11. PPI: output of manufacturing division $(2011-12=100$, SA by author $)$

12. PPI: input to manufacturing division $(2011-12=100$, SA by author)

13. PPI: input to manufacturing division $(2011-12=100$, SA by author)

14. PPI: input to manufacturing : imported mat $(2011-12=100$, SA by author $)$

15. PPI: input to manufacturing : domestic mat. $(2011-12=100$, SA by author) 4

16. PPI: input to manufacturing : natural gas $(2011-12=100$, SA by author 4

17. PPI: input to manufacturing : electricity $(2011-12=100$, SA by author $) 4$

18. PPI: input to house construction : all groups $(2011-12=100$, SA by author $) 4$

19. import price index $(2011-12=100$, SA by author $)$

20. export price index (2011-12 = 100, SA by author)

21. implicit price deflator of GDP $(2011-12=100, \mathrm{SA})$
ABS 6401.0

ABS 6401.0

ABS 6401.0

ABS 6401.0

ABS 6401.0

ABS 6401.0

ABS 6401.0

ABS 6401.0

ABS 6401.0

ABS 6401.0

ABS 6427.0

ABS 6427.0

ABS 6427.0

ABS 6427.0

ABS 6427.0

ABS 6427.0

ABS 6427.0

ABS 6427.0

ABS 6457.0

ABS 6457.0

ABS 5206.0 


\begin{tabular}{|c|c|c|c|}
\hline 1. & IPindex $(2010-11=100$, SA $)$ & 4 & DS (AUQ66CE) \\
\hline 2. & IPindex: mining: excluding exploration and serv. $(2011-12=100, \mathrm{SA})$ & 4 & ABS 5206.0 \\
\hline 3. & IPindex: mining $(2011-12=100, \mathrm{SA})$ & 4 & ABS 5206.0 \\
\hline 4. & IPindex: electricity, gas, water and waste services $(2011-12=100, \mathrm{SA})$ & 4 & ABS 5206.0 \\
\hline 5. & IPindex: total industrial industries $(2011-12=100, \mathrm{SA})$ & 4 & ABS 5206.0 \\
\hline 6. & IPindex: manufacturing: food, beverage and tobacco $(2011-12=100, \mathrm{SA})$ & 4 & ABS 5206.0 \\
\hline 7. & IPindex: manufacturing: textile, clothing $(2011-12=100, \mathrm{SA})$ & 4 & ABS 5206.0 \\
\hline 8. & IPindex: manufacturing: wood and paper products $(2011-12=100, \mathrm{SA})$ & 4 & ABS 5206.0 \\
\hline 9. & IPindex: manufacturing: printing and recorded media $(2011-12=100, \mathrm{SA})$ & 4 & ABS 5206.0 \\
\hline 10. & IPindex: manufacturing: petroleum, coal, etc $(2011-12=100, \mathrm{SA})$ & 4 & ABS 5206.0 \\
\hline 11. & IPindex: manufacturing: non-metallic mineral products $(2011-12=100, \mathrm{SA})$ & & ABS 5206.0 \\
\hline 12. & IPindex: manufacturing: metal products $(2011-12=100, \mathrm{SA})$ & 4 & ABS 5206.0 \\
\hline 13. & IPindex : manufacturing: machinery and equipment $(2011-12=100, \mathrm{SA})$ & 4 & ABS 5206.0 \\
\hline 14. & household gross disposable income (current prices, \$mil, SA) & 4 & ABS 5206.0 \\
\hline 15. & GDP: non-farm (CVM, \$mil, SA) & 4 & ABS 5206.0 \\
\hline 16. & GDP: farm (CVM, \$mil, SA) & 4 & ABS 5206.0 \\
\hline 17. & household consumption share of current prices nominal GDP (\%, SA) & 2 & RBA stat. Table H2 \\
\hline 18. & dwelling investment share of current prices nominal GDP $(\%, \mathrm{SA})$ & 2 & RBA stat. Table H2 \\
\hline 19. & business investment share of current prices nominal GDP $(\%, \mathrm{SA})$ & 2 & RBA stat. Table H2 \\
\hline 20. & public demand share of current prices nominal GDP $(\%, \mathrm{SA})$ & 2 & RBA stat. Table H2 \\
\hline 21. & $\begin{array}{l}\text { private non-financial corporations gross operating surplus share of current } \\
\text { prices nominal GDP }(\%, \mathrm{SA})\end{array}$ & 2 & RBA stat. Table H2 \\
\hline
\end{tabular}

\begin{tabular}{|c|c|c|c|}
\hline \multicolumn{4}{|c|}{ Retail Trade } \\
\hline 1. & retail turnover per capita - (CVM, \$mil, SA) & 4 & ABS 8501.0 \\
\hline 2. & retail turnover: food retailing $(\mathrm{CVM}, \$$ mil, $\mathrm{SA})$ & 4 & ABS 8501.0 \\
\hline 3. & retail turnover: household goods retailing (CVM, \$mil, SA) & 4 & ABS 8501.0 \\
\hline 4. & retail turnover: clothing, footwear and personal retailing (CVM, \$mil, SA) & 4 & ABS 8501.0 \\
\hline 5. & retail turnover: department stores (CVM, \$mil, SA) & 4 & ABS 8501.0 \\
\hline 6. & retail turnover: other retailing (CVM, \$mil, SA) & 4 & ABS 8501.0 \\
\hline 7. & retail turnover: cafes, restaurants and takeaway, etc (CVM, \$mil, SA) & 4 & ABS 8501.0 \\
\hline 8. & retail turnover: all components (CVM, \$mil, SA) & 4 & ABS 8501.0 \\
\hline \multicolumn{4}{|c|}{ Stock prices } \\
\hline 1. & S\&P/ASX 100 price index (NSA) & 4 & DS (ASX100I) \\
\hline 2. & S\&P/ASX 100: industrials price index (NSA) & 4 & DS (ASX1IND) \\
\hline 3. & S\&P/ASX 100: resources price index (NSA) & 4 & DS (ASX1RES) \\
\hline 4. & S\&P/ASX 200 price index (NSA) & 4 & DS (ASX200I) \\
\hline 5. & S\&P/ASX 200: industrials price index (NSA) & 4 & DS (ASX2IND) \\
\hline 6. & S\&P/ASX 200: resources price index (NSA) & 4 & DS (ASX2RES) \\
\hline 7. & S\&P/ASX 300 price index (NSA) & 4 & DS (ASX300I) \\
\hline 8. & S\&P/ASX 300: industrials price index (NSA) & 4 & DS (ASX3IND) \\
\hline 9. & S\&P/ASX 300: resources price index (NSA) & 4 & DS (ASX3RES) \\
\hline 10. & ASX all ordinaries price index $(1980=500, \mathrm{NSA})$ & 4 & DS (AUSTOLD) \\
\hline
\end{tabular}




\section{Appendix B - Unit root tests on Taylor Rule series}

Table B.1: Unit root tests on Taylor Rule series

\begin{tabular}{|c|c|c|}
\hline Series & ADF & KPSS \\
\hline Cash target rate & $-3.675(-2.899)\{1\}$ & $0.401(0.463)\{6\}$ \\
\hline Headline CPI & $-4.386(-2.899)\{1\}$ & $0.141(0.463)\{5\}$ \\
\hline Trimmed mean CPI & $-2.749(-2.899)\{5\}$ & $0.245(0.463)\{6\}$ \\
\hline \multirow[t]{2}{*}{ Weighted median CPI } & $-2.578(-2.899)\{5\}$ & $0.460(0.463)\{6\}$ \\
\hline & & ADF \\
\hline Output gap - linear trend & $-1.564(-1.945)\{0\}$ & \\
\hline Output gap - HP filter & $-2.706(-1.945)\{0\}$ & \\
\hline Unemployment gap - HP filter & $-2.535(-1.945)\{1\}$ & \\
\hline \multicolumn{3}{|c|}{$\begin{array}{l}\text { Notes: sample 1994Q1 - 2013Q1. The reported values are test statistics with associated 5\% critical values } \\
\text { appearing in parentheses. Bold font indicates where the two tests provide contradictory results. ADF tests: the } \\
\text { null hypothesis of this test is that the series has a unit root. Lag length is determined automatically using the } \\
\text { Bayesian information criterion (Schwarz 1978), with maximum lag length set equal to 12. An intercept is } \\
\text { included for all series other than the output/unemployment gap series. Lag length for each test appears in braces. } \\
\text { KPSS tests: the null hypothesis of this test is that the series is stationary. Spectral estimation method is the } \\
\text { Bartlett kernel. Bandwidth is determined automatically using the Newey-West (1994) fixed bandwidth. Only an } \\
\text { intercept is included for all series tested. This test is not performed on output/unemployment gap series, as an } \\
\text { intercept must be included in the test equation of this test. Bandwidth for each test appears in braces. }\end{array}$} \\
\hline
\end{tabular}




\section{Appendix C - Eigenvalue Ratio Test}

Table C.1 : Eigenvalue ratio test

\begin{tabular}{|c|c|c|c|c|c|}
\hline $\begin{array}{l}\text { Variable group } \\
\text { category }\end{array}$ & No. of PC & Eigenvalue & $\begin{array}{l}\text { Eigenvalue } \\
\text { ratio }\end{array}$ & Proportion & $\begin{array}{l}\text { Cumulative } \\
\text { Proportion }\end{array}$ \\
\hline \multirow{3}{*}{$\begin{array}{c}\text { Building } \\
\text { approvals }\end{array}$} & 1 & 11.076 & 4.440 & 0.554 & 0.554 \\
\hline & 2 & 2.495 & 1.552 & 0.125 & 0.679 \\
\hline & 3 & 1.607 & 1.300 & 0.080 & 0.759 \\
\hline \multirow{3}{*}{$\begin{array}{l}\text { Changes in } \\
\text { inventories }\end{array}$} & 1 & 3.155 & 2.443 & 0.451 & 0.451 \\
\hline & 2 & 1.291 & 1.125 & 0.185 & 0.635 \\
\hline & 3 & 1.147 & 1.408 & 0.164 & 0.799 \\
\hline \multirow{3}{*}{$\begin{array}{l}\text { Commodity } \\
\text { prices }\end{array}$} & 1 & 10.470 & 1.516 & 0.403 & 0.403 \\
\hline & 2 & 6.904 & 3.082 & 0.266 & 0.668 \\
\hline & 3 & 2.240 & 1.171 & 0.086 & 0.754 \\
\hline \multirow[t]{3}{*}{ Consumption } & 1 & 4.483 & 1.453 & 0.204 & 0.204 \\
\hline & 2 & 3.086 & 1.363 & 0.140 & 0.344 \\
\hline & 3 & 2.265 & 1.442 & 0.103 & 0.447 \\
\hline \multirow{3}{*}{$\begin{array}{l}\text { Domestic interest } \\
\text { rates }\end{array}$} & 1 & 6.522 & 3.556 & 0.652 & 0.652 \\
\hline & 2 & 1.834 & 1.961 & 0.183 & 0.836 \\
\hline & 3 & 0.935 & 1.683 & 0.094 & 0.929 \\
\hline \multirow[t]{3}{*}{ Employment } & 1 & 9.002 & 2.226 & 0.225 & 0.225 \\
\hline & 2 & 4.044 & 1.255 & 0.101 & 0.326 \\
\hline & 3 & 3.223 & 1.195 & 0.081 & 0.407 \\
\hline \multirow{3}{*}{$\begin{array}{c}\text { Foreign } \\
\text { exchange rates }\end{array}$} & 1 & 6.096 & 7.336 & 0.677 & 0.677 \\
\hline & 2 & 0.831 & 1.089 & 0.092 & 0.770 \\
\hline & 3 & 0.763 & 1.597 & 0.085 & 0.854 \\
\hline \multirow{3}{*}{$\begin{array}{l}\text { International } \\
\text { interest rates }\end{array}$} & 1 & 6.186 & 1.710 & 0.412 & 0.412 \\
\hline & 2 & 3.618 & 3.064 & 0.241 & 0.654 \\
\hline & 3 & 1.181 & 1.033 & 0.079 & 0.732 \\
\hline \multirow{3}{*}{$\begin{array}{l}\text { Monetary and } \\
\text { credit aggregates }\end{array}$} & 1 & 4.881 & 1.631 & 0.245 & 0.245 \\
\hline & 2 & 2.993 & 1.542 & 0.150 & 0.395 \\
\hline & 3 & 1.941 & 1.129 & 0.097 & 0.492 \\
\hline \multirow[t]{3}{*}{ Price indexes } & 1 & 5.842 & 2.021 & 0.278 & 0.278 \\
\hline & 2 & 2.891 & 1.420 & 0.138 & 0.416 \\
\hline & 3 & 2.036 & 1.249 & 0.097 & 0.513 \\
\hline \multirow{3}{*}{$\begin{array}{l}\text { Real output and } \\
\text { income }\end{array}$} & 1 & 3.992 & 1.848 & 0.190 & 0.190 \\
\hline & 2 & 2.160 & 1.108 & 0.103 & 0.293 \\
\hline & 3 & 1.949 & 1.187 & 0.093 & 0.386 \\
\hline \multirow[t]{3}{*}{ Retail trade } & 1 & 4.464 & 3.842 & 0.558 & 0.558 \\
\hline & 2 & 1.162 & 1.280 & 0.145 & 0.703 \\
\hline & 3 & 0.908 & 1.438 & 0.114 & 0.817 \\
\hline \multirow[t]{3}{*}{ Stock prices } & 1 & 8.331 & 5.113 & 0.833 & 0.833 \\
\hline & 2 & 1.629 & 78.153 & 0.163 & 0.996 \\
\hline & 3 & 0.021 & 1.997 & 0.002 & 0.998 \\
\hline
\end{tabular}


Table 1: Estimated Taylor Rules with different specifications (Equation 3)

\begin{tabular}{lccccccccc}
\hline & \multicolumn{3}{c}{ Output gap - linear trend } & \multicolumn{3}{c}{ Output gap - HP filter } & \multicolumn{3}{c}{ Unemployment gap - HP filter } \\
\hline & $\mathbf{H}$ & $\mathbf{T M}$ & $\mathbf{W M}$ & $\mathbf{H}$ & $\mathbf{T M}$ & $\mathbf{W M}$ & $\mathbf{H}$ & TM & WM- \\
\hline$\delta$ & $0.83^{* * *}$ & $0.82^{* *}$ & $0.88^{* *}$ & $0.71^{* *}$ & 0.62 & 0.65 & $0.86^{* * *}$ & $0.86^{* *}$ & $0.88^{*}$ \\
& $(2.97)$ & $(2.01)$ & $(2.06)$ & $(2.61)$ & $(1.63)$ & $(1.58)$ & $(2.70)$ & $(2.09)$ & $(1.95)$ \\
$\left(1+\beta_{\pi}\right)$ & $\mathbf{0 . 0 1}$ & $\mathbf{0 . 0 0 1}$ & $\mathbf{- 0 . 0 3}$ & $\mathbf{0 . 0 0}$ & $\mathbf{0 . 0 6}$ & $\mathbf{0 . 0 2}$ & $\mathbf{- 0 . 0 4}$ & $\mathbf{0 . 0 0}$ & $\mathbf{- 0 . 0 1}$ \\
& $(0.26)$ & $(0.05)$ & $(-0.38)$ & $(0.12)$ & $(0.58)$ & $(0.29)$ & $(-0.98)$ & $(0.04)$ & $(-0.09)$ \\
$\beta_{\mathrm{y}}$ & $\mathbf{0 . 0 5 * *}$ & $\mathbf{0 . 0 5 * * *}$ & $\mathbf{0 . 0 4 * *}$ & $\mathbf{0 . 1 1} 1^{* *}$ & $\mathbf{0 . 1 3} * * *$ & $\mathbf{0 . 1 2} * * *$ & $\mathbf{- 0 . 2 0 *}$ & $\mathbf{- 0 . 2 1} *$ & $\mathbf{- 0 . 2 0 *}$ \\
& $(2.13)$ & $(2.84)$ & $(2.11)$ & $(2.10)$ & $(2.91)$ & $(2.97)$ & $(-1.99)$ & $(-2.04)$ & $(-1.85)$ \\
$\rho_{1}+\rho_{2}$ & $0.84^{* * *}$ & $0.84^{* * *}$ & $0.85^{* * *}$ & $0.85^{* * *}$ & $0.83^{* * *}$ & $0.85^{* * *}$ & $0.85^{* * *}$ & $0.83^{* * *}$ & $0.83^{* * *}$ \\
& $(16.68)$ & $(21.04)$ & $(17.27)$ & $(16.29)$ & $(18.83)$ & $(17.50)$ & $(14.83)$ & $(15.35)$ & $(14.98)$ \\
\hline $\mathrm{R}^{2}$ & 0.93 & 0.93 & 0.93 & 0.93 & 0.93 & 0.93 & 0.93 & 0.93 & 0.93 \\
Adj. $\mathrm{R}^{2}$ & 0.93 & 0.93 & 0.93 & 0.93 & 0.93 & 0.93 & 0.93 & 0.93 & 0.93 \\
$\mathrm{H}_{0}:$ no SC & 0.55 & 0.62 & 0.53 & 0.64 & 0.48 & 0.60 & 0.52 & 0.39 & 0.39 \\
\hline
\end{tabular}

Notes: $\mathrm{H}$ indicates headline CPI inflation, TM is trimmed mean CPI inflation and WM represents weighted median CPI inflation.The sample period is 1994Q1-2013Q1.***,** and * indicates coefficient is significantly different from zero at a $1 \%, 5 \%$ and $10 \%$ level of significance, respectively. t-statistics appear in parentheses. Following de Brouwer and Gilbert (2005), errors are corrected for heteroscedasticity and serial correlation using the Newey-West (1987) procedure. The t-statistic associated with $\rho_{1}+\rho_{2}$ is calculated under the null hypothesis that the sum of the interest rate smoothing coefficients is equal to zero. The null hypothesis no SC refers the Breusch-Godfrey test for serial correlation (Breusch 1978; Godfrey 1978a; Godfrey 1978b). The stated values for this test are the P-values associated with the $\chi^{2}$-statistic. The null hypothesis of no serial correlation of up to lag order eight is not rejected at a ten $\%$ level of significance. With respect to $1+\beta_{\pi}$ or $\beta_{\mathrm{y}}$, bold typeface denotes that the coefficient is significantly different from Taylor's (1993) parameterisation $\left(1+\beta_{\pi}=1.5, \beta_{\mathrm{y}}=0.5\right)$ at a $5 \%$ level of significance; or when considering the unemployment gap, the parameterisation implied by Okun's law $(1962)\left(\beta_{y}=-1.25\right)$.

Table 2: Determinants of Taylor's Rule deviation (Equation 4) using alternative measures of the output gap and inflation

\begin{tabular}{|c|c|c|c|c|c|c|c|c|c|}
\hline & \multicolumn{3}{|c|}{ Output gap - linear trend } & \multicolumn{3}{|c|}{ Output gap - HP filter } & \multicolumn{3}{|c|}{ Unemployment gap - HP filter } \\
\hline & $\begin{array}{l}\mathbf{H} \\
\end{array}$ & TM & $\mathbf{W M}$ & $\begin{array}{l}\mathbf{H} \\
\end{array}$ & TM & $\mathbf{W M}$ & $\mathbf{H}$ & TM & WM \\
\hline$\delta$ & 0.000 & 0.000 & 0.000 & 0.000 & 0.000 & 0.000 & 0.000 & 0.000 & 0.000 \\
\hline & $(0.000)$ & $(0.000)$ & $(0.000)$ & $(0.000)$ & $(0.000)$ & $(0.000)$ & $(0.000)$ & $(0.000)$ & $(0.000)$ \\
\hline$\beta_{1}$ & $\begin{array}{c}0.262 * * * \\
(3.855)\end{array}$ & $\begin{array}{c}0.265 * * * \\
(3.908)\end{array}$ & $\begin{array}{c}0.273 * * * \\
(3.853)\end{array}$ & $\begin{array}{c}0.281 * * * \\
(4.166)\end{array}$ & $\begin{array}{c}0.280 * * * \\
(4.033)\end{array}$ & $\begin{array}{c}0.278 * * * \\
(4.213)\end{array}$ & $\begin{array}{c}0.280 * * * \\
(3.564)\end{array}$ & $\begin{array}{c}0.276 * * * \\
(3.413)\end{array}$ & $\begin{array}{c}0.278 * * * \\
(3.443)\end{array}$ \\
\hline$\beta_{2}$ & $\begin{array}{c}0.066 * * * \\
(4.963)\end{array}$ & $\begin{array}{c}0.066 * * * \\
(5.031)\end{array}$ & $\begin{array}{c}0.068 * * * \\
(5.648)\end{array}$ & $\begin{array}{c}0.063 * * * \\
(6.650)\end{array}$ & $\begin{array}{c}0.060 * * * \\
(5.764)\end{array}$ & $\begin{array}{c}0.062 * * * \\
(6.357)\end{array}$ & $\begin{array}{c}0.057 * * * \\
(5.282)\end{array}$ & $\begin{array}{c}0.058 * * * \\
(4.980)\end{array}$ & $\begin{array}{c}0.059^{* * * *} \\
(5.130)\end{array}$ \\
\hline$\beta_{3}$ & $\begin{array}{c}-0.033 * * \\
(-2.617)\end{array}$ & $\begin{array}{c}-0.033 * * \\
(-2.644)\end{array}$ & $\begin{array}{c}-0.035 * * * \\
(-2.710)\end{array}$ & $\begin{array}{c}-0.048 * * * \\
(-3.196)\end{array}$ & $\begin{array}{c}-0.048 * * * \\
(-3.102)\end{array}$ & $\begin{array}{c}-0.048 * * * \\
(-3.244)\end{array}$ & $\begin{array}{l}-0.035^{*} \\
(-1.946)\end{array}$ & $\begin{array}{l}-0.032^{*} \\
(-1.710)\end{array}$ & $\begin{array}{l}-0.032 * \\
(-1.754)\end{array}$ \\
\hline$\beta_{4}$ & $\begin{array}{c}0.011 \\
(1.500)\end{array}$ & $\begin{array}{c}0.011 \\
(1.510)\end{array}$ & $\begin{array}{c}0.012 \\
(1.448)\end{array}$ & $\begin{array}{c}0.017 * * \\
(2.154)\end{array}$ & $\begin{array}{c}0.019 * * \\
(2.415)\end{array}$ & $\begin{array}{c}0.018^{* * *} \\
(2.281)\end{array}$ & $\begin{array}{c}0.020^{* *} \\
(2.136)\end{array}$ & $\begin{array}{c}0.019 * * \\
(2.018)\end{array}$ & $\begin{array}{l}0.019 * \\
(1.976)\end{array}$ \\
\hline$\beta_{5}$ & $\begin{array}{c}0.037 * * * \\
(3.926)\end{array}$ & $\begin{array}{c}0.037 * * * \\
(3.889)\end{array}$ & $\begin{array}{c}0.036 * * * \\
(3.699)\end{array}$ & $\begin{array}{c}0.034 * * * \\
(3.234)\end{array}$ & $\begin{array}{c}0.035 * * * \\
(3.180)\end{array}$ & $\begin{array}{c}0.035 * * * \\
(3.321)\end{array}$ & $\begin{array}{c}0.029 * * \\
(2.542)\end{array}$ & $\begin{array}{c}0.027 * * \\
(2.397)\end{array}$ & $\begin{array}{c}0.027 * * \\
(2.406)\end{array}$ \\
\hline $\mathrm{R}^{2}$ & 0.669 & 0.668 & 0.676 & 0.655 & 0.644 & 0.650 & 0.616 & 0.606 & 0.611 \\
\hline Adj. $R^{2}$ & 0.645 & 0.644 & 0.653 & 0.631 & 0.619 & 0.625 & 0.589 & 0.578 & 0.583 \\
\hline $\mathrm{H}_{0}$ : no SC & 0.278 & 0.314 & 0.341 & 0.633 & 0.774 & 0.726 & 0.298 & 0.082 & 0.093 \\
\hline
\end{tabular}


Table 3: The LMG - Shapley decomposition of equation (16)

\begin{tabular}{ccccccc}
\hline & COMM $_{t}$ & DOMIR $_{t}$ & EXRATE $_{t}$ & INTIR $_{t}$ & USDEV $_{t}$ & Total \\
\hline $\bar{R}_{x_{t 1}{ }^{2}}^{2}$ & 0.125 & 0.225 & 0.160 & 0.048 & 0.086 & 0.644 \\
$\bar{R}_{x_{t j}}^{2}$ & 0.194 & 0.349 & 0.248 & 0.075 & 0.133 & 1.000 \\
\hline
\end{tabular}

Notes: The sample period is 1994Q1-2013Q1.

Figure 1: Three measures of inflation from 1994Q1 to 2013Q1

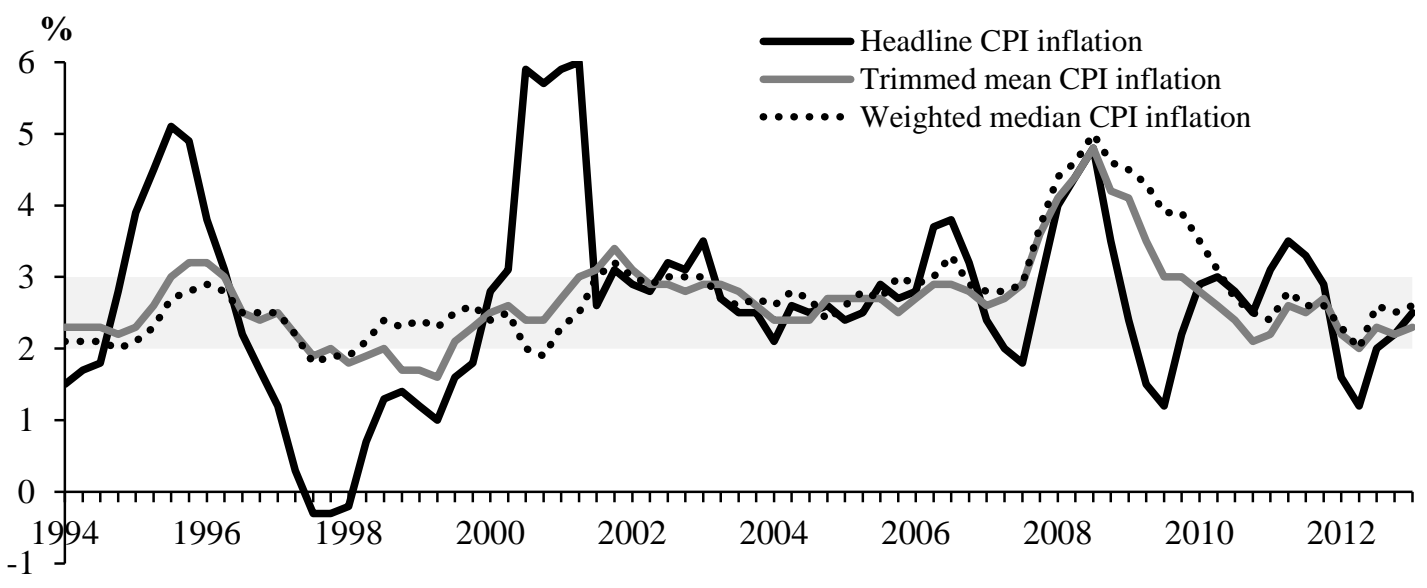

Figure 2: Three measures of output gap (real-time data) 1994Q1 to 2013Q1

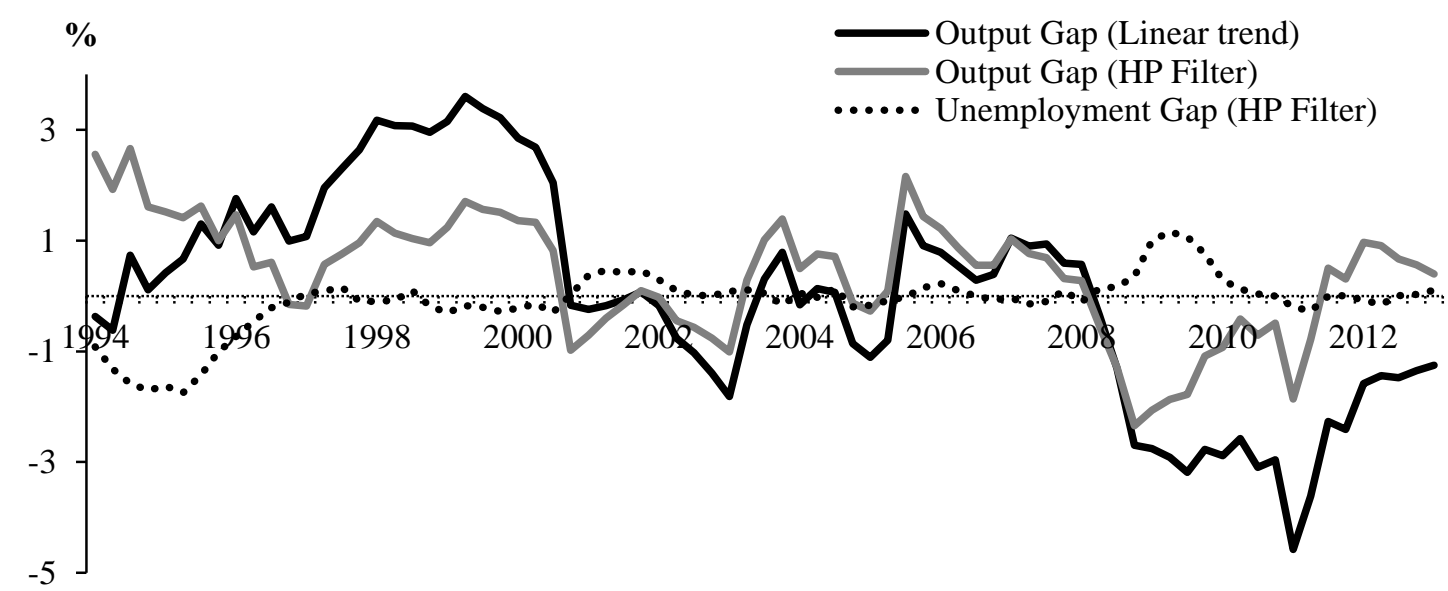


Figure 3a: Estimated fitted value of the Taylor Rule and the cash rate

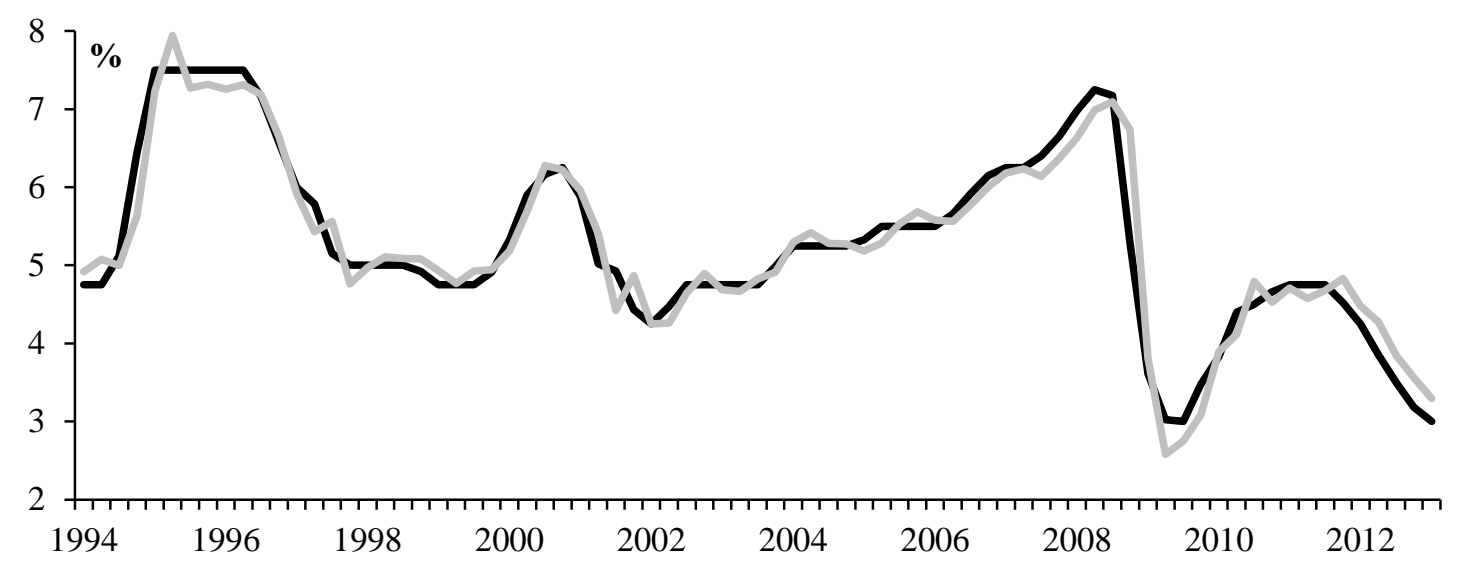

Figure 3b: Deviation of Taylor Rule from cash rate

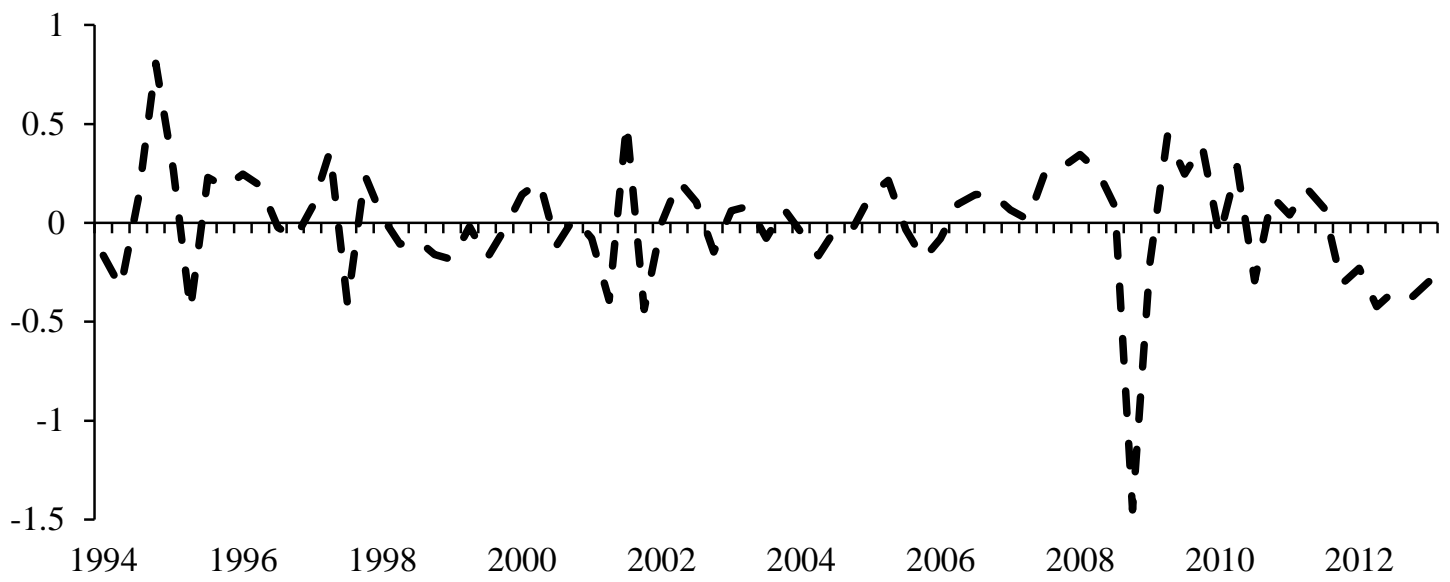

Figure 4: The range of Taylor Rule for alternative measures of inflation and output gap

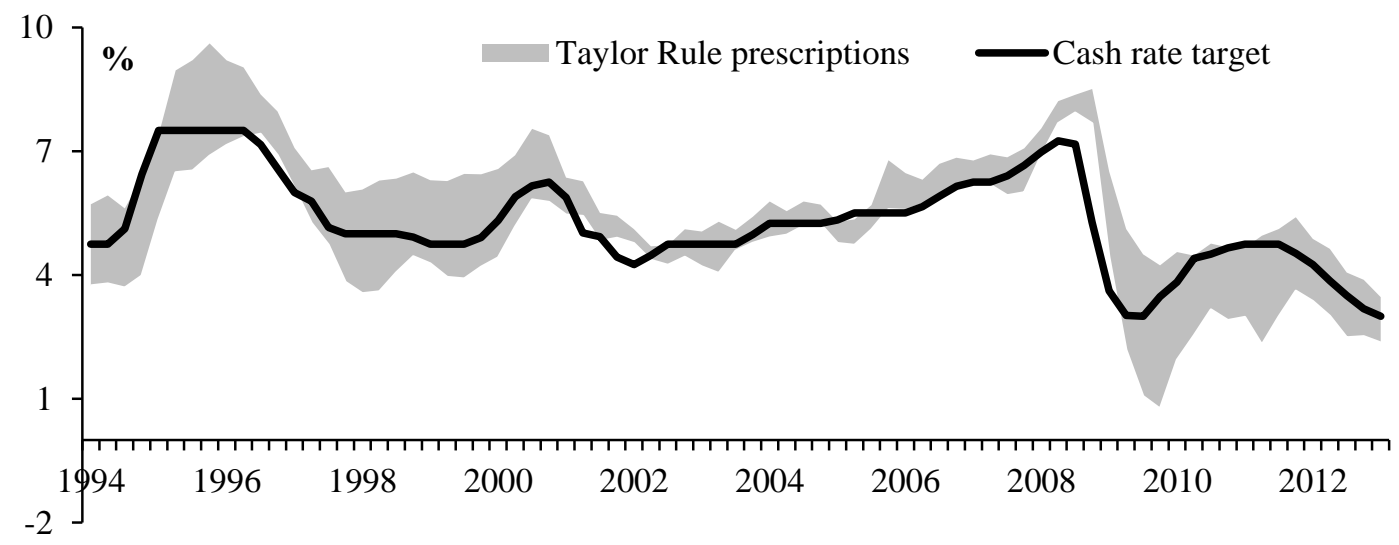




\section{TASMANIAN SCHOOL OF BUSINESS AND ECONOMICS WORKING PAPER SERIES}

2014-14 VAR(MA), What is it Good For? More Bad News for Reduced-form Estimation and Inference, Wenying Yao, Timothy Kam and Farshid Vahid

2014-13 OPEC and non-OPEC oil production and the global economy, Ronald Ratti and Joaquin Vespignani

2014-12 Identifying Periods of Financial Stress in Asian Currencies: The Role of High Frequency Financial Market Data, Mardi Dungey, Marius Matei and Sirimon Treepongkaruna

2014-11 The impact of post-IPO changes in corporate governance mechanisms on firm performance: evidence from young Australian firms, Biplob Chowdhury, Mardi Dungey and Thu Phuong Pham

2014-10 Contagion and Banking Crisis - International Evidence for 2007-2009， Mardi Dungey and Dinesh Gajurel

2014-09 VAR Modelling in the Presence of China's Rise: An Application to the Taiwanese Economy. Mardi Dungey, Tugrul Vehbi and Charlton Martin

2014-08 How Many Stocks are Enough for Diversifying Canadian Institutional Portfolios? Vitali Alexeev and Francis Tapon

2014-07 Forecasting with EC-VARMA Models, George Athanasopoulos, Don Poskitt, Farshid Vahid, Wenying Yao

2014-06 Canadian Monetary Policy Analysis using a Structural VARMA Model, Mala Raghavan, George Athanasopoulos, Param Silvapulle

2014-05 The sectorial impact of commodity price shocks in Australia, S. Knop and Joaquin Vespignani

2014-04 Should ASEAN-5 monetary policymakers act pre-emptively against stock market bubbles? Mala

Raghavan and Mardi Dungey

2014-03 Mortgage Choice Determinants: The Role of Risk and Bank Regulation, Mardi Dungey, Firmin Doko Tchatoka, Graeme Wells, Maria B. Yanotti

2014-02 Concurrent momentum and contrarian strategies in the Australian stock market, Minh Phuong Doan, Vitali Alexeev, Robert Brooks

2014-01 A Review of the Australian Mortgage Market, Maria B. Yanotti 